\section{OAK RIDGE NATIONAL LABORATORY}

MARTIN MARIETTA

\section{Analytical Results of Physics Specimens and Dosimeters in Fuel Pins 1,2 , and 4, Irradiated in the Dounreay Prototype Fast Reactor}
R. L. Walker
J. L. Botts
R. J. Hydzik
J. M. Keller
J. K. Dickens
S. Raman 
This report has boen reproduced directly from the best available copy.

Available to DOE and DOE contractors from the Office of Scientific and Technical Information, P.O. Box 62, Oak Ridge, TN 37831; prices available from (615) 576-8401, FTS 626-8401.

Available to the public from the National Technical Information Service, U.S. Department of Commerce, 5285 Port Royal Rd., Springfield, VA 22161.

This report was prepared as an account of work sponsored by an agency of the United States Government. Neither the United States Government nor any agency thereof, nor any of their employees, makes any warranty, express or implied, or assumes any legal liability or responsibility for the accuracy, completeness, or usefulness of any information, apparatus, product, or process disclosed, or represents that its use would not infringe privately owned rights. Reference herein to any specific commercial product, process, or service by trade name, trademark, manufacturer, or otherwise, does not necessarily constitute or imply its endorsement, recommendation, or favoring by the United States Government or any agency thereof. The views and opinions of authors expressed herein do not necessarily state or reflect those of the United States Government or any agency thereof. 


\section{DISCLAIMER}

Portions of this document may be illegible in electronic image products. Images are produced from the best available original document. 


\title{
ANALYTICAL RESULTS OF PHYSICS SPECIMENS AND DOSIMETERS IN FUEL PINS 1, 2, AND 4 IRRADIATED IN THE DOUNREAY PROTOTYPE FAST REACTOR
}

\author{
R. L. Walker \\ J. L. Botts \\ R. J. Hydzik \\ J. M. Keller \\ J. K. Dickens \\ S. Raman
}

Date Published: December 1994

Prepared by

OAK RIDGE NATIONAL LABORATORY

Oak Ridge, Tennessee 37831

managed by

MARTIN MARIETTA ENERGY SYSTEMS, INC.

for the

U.S. DEPARTMENT OF ENERGY

under contract DE-AC05-84OR21400 


\section{TABLE OF CONTENTS}

LIST OF FIGURES $\ldots \ldots \ldots \ldots \ldots \ldots \ldots \ldots \ldots \ldots \ldots \ldots \ldots \ldots \ldots \ldots \ldots$ iii

LIST OF TABLES $\ldots \ldots \ldots \ldots \ldots \ldots \ldots \ldots \ldots \ldots \ldots \ldots \ldots \ldots \ldots, \mathrm{v}$

ACKNOWLEDGMENTS $\ldots \ldots \ldots \ldots \ldots \ldots \ldots \ldots \ldots \ldots \ldots \ldots \ldots$ vii

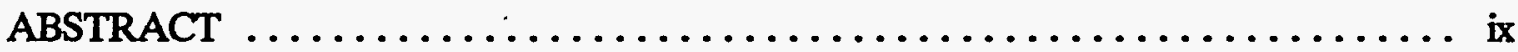

1. INTRODUÇTION $\ldots \ldots \ldots \ldots \ldots \ldots \ldots \ldots \ldots \ldots \ldots \ldots \ldots \ldots \ldots \ldots \ldots$

2. PHYSICS SPECIMEN MATERIALS AND DOSIMETERS IRRADIATED IN THE U.S-U.K. HIGHER ACTINIDE EXPERIMENT $\ldots \ldots \ldots \ldots \ldots \ldots \ldots \ldots, 2$

3. METHODS USED FOR ACTINIDE ANALYSIS $\ldots \ldots \ldots \ldots \ldots \ldots \ldots \ldots, 4$

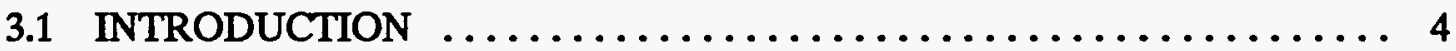

3.2 DISSOLUTION OF ACTINIDE PHYSICS SPECIMENS AND DOSIMETER

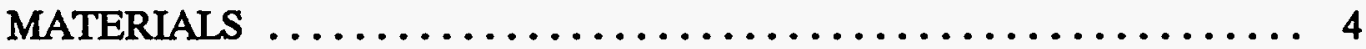

3.2.1 Arrangement of FP Assembly $\ldots \ldots \ldots \ldots \ldots \ldots \ldots \ldots \ldots \ldots, 4$

3.2.2 Removal and Identification of Specimens and Dosimeters ........ 4

3.2.3 Reagents and Glassware $\ldots \ldots \ldots \ldots \ldots \ldots \ldots \ldots \ldots \ldots .5$

3.2.4 Summary of Techniques Used for Dissolution of Physics Specimens .. 5

3.2.5 Problems Causing Loss of Sample $\ldots \ldots \ldots \ldots \ldots \ldots \ldots \ldots, 6$

3.2.6 Dissolution of Dosimeters ...................... 6

3.3 DESCRIPTION OF MASS SPECTROMETER USED FOR ACTINIDES ANALYSIS .............................. 6

3.4 DESCRIPTION OF RADIOMETRIC METHODS USED FOR ACTINIDE ANALYSIS $\ldots \ldots \ldots \ldots \ldots \ldots \ldots \ldots \ldots \ldots \ldots \ldots \ldots \ldots \ldots \ldots \ldots \ldots \ldots$

3.4.1 Plutonium-238 ............................... 10

3.4.2 Americium and Curium $\ldots \ldots \ldots \ldots \ldots \ldots \ldots \ldots \ldots \ldots \ldots \ldots \ldots$

3.4.3 Neptunium-237 ............................ 11

3.4.4 Protactinium-231 $\ldots \ldots \ldots \ldots \ldots \ldots \ldots \ldots \ldots \ldots \ldots \ldots \ldots, 11$

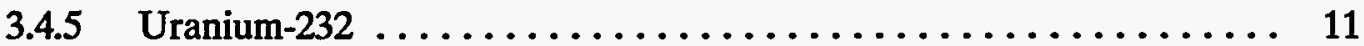

4. RESULTS AND DISCUSSION OF ACTINIDE ANALYSIS $\ldots \ldots \ldots \ldots \ldots 12$

5. GAMMA-RAY ASSAY MEASUREMENTS OF FP-4 SAMPLES FOR FISSION

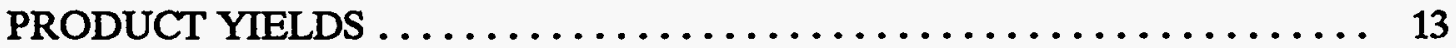

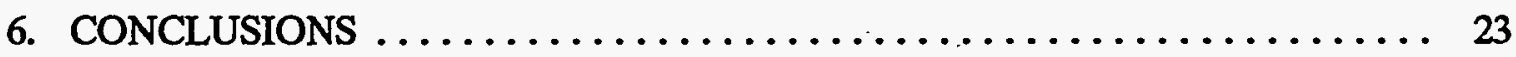

REFERENCES $\ldots \ldots \ldots \ldots \ldots \ldots \ldots \ldots \ldots \ldots \ldots \ldots \ldots \ldots \ldots \ldots \ldots \ldots \ldots \ldots \ldots, 24$ 


\section{LIST OF FIGURES}

Figure

Page

1 Sample locations for physics specimens and dosimeter capsules in fuel pins $\ldots \ldots \ldots \ldots \ldots \ldots \ldots \ldots \ldots \ldots \ldots \ldots \ldots$

2 Mass spectrometer for analysis of actinides $\ldots \ldots \ldots \ldots \ldots \ldots \ldots \ldots \ldots \ldots$

3 Electronic console for mass spectrometer $\ldots \ldots \ldots \ldots \ldots \ldots \ldots \ldots \ldots \ldots$ 


\section{LIST OF TABLES}

Table

1. Physics specimen materials selected for irradiation $\ldots \ldots \ldots \ldots \ldots \ldots \ldots \ldots$

2. Dosimeter materials selected for irradiation $\ldots \ldots \ldots \ldots \ldots \ldots \ldots \ldots \ldots \ldots$

3. Mixed plutonium and uranium standards on resin beads $\ldots \ldots \ldots \ldots \ldots \ldots \ldots$

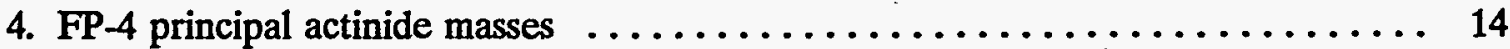

5. Nuclear data for fission products $\ldots \ldots \ldots \ldots \ldots \ldots \ldots \ldots \ldots \ldots \ldots \ldots$

6. Absolute experimental yields (in the aliquots) of the fission product ${ }^{137} \mathrm{Cs}$ as of the end of the PFR irradiation $\ldots \ldots \ldots \ldots \ldots \ldots \ldots \ldots \ldots \ldots \ldots \ldots$

7. FP-4: yields of fission products deduced by gamma-ray assay $\ldots \ldots \ldots \ldots \ldots$

8. FP-4: yields of shielded radionuclides deduced by gamma-ray assay $\ldots \ldots \ldots$. . . 19

9. FP-4: comparison of post-irradiation actinide sample masses measured by two methods. ................................. 20

10. FP-4: actinides produced in neutron capture by principal isotopes deduced by gamma-

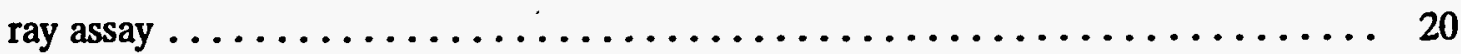

11. FP-4: yields of actinides other than principal and capture nuclides as deduced by gamma-ray assay $\ldots \ldots \ldots \ldots \ldots \ldots \ldots \ldots \ldots \ldots \ldots \ldots \ldots \ldots \ldots$

12. FP-4: dosimeter yields deduced by gamma-ray assay $\ldots \ldots \ldots \ldots \ldots \ldots \ldots \ldots 22$ 



\section{ACKNOWLEDGMENTS}

We thank P. B. Hemmig (USDOE), K. M. Swanson (UKAEA), C. Brown (UKAEA), and T. Mukaiyama (JAERI) for their interest in this work, cooperation, and tangible support. This report was read critically by B. D. Murphy (ORNL) and T. D. Newton (UKAEA).

We express our appreciation to the many people of the Analytical Chemistry Division who contributed to the dissolution and preparation of our samples. A special thanks to M. W. Haskew for his contributions. Thanks also to J. A. Carter, D. A. Costanzo, J. M. Peele, C. A. Pritchard, and others who guided, advised, or analyzed these difficult samples. We also thank Doris C. Smith and Ann M. McCoy for their untiring efforts in preparing the reports and being so tolerant of us in making changes, corrections, and rewrites. Our thanks also to D. H. Smith and R. W. Sharpe for their help in technical proofreading. 


\begin{abstract}
The United States and the United Kingdom have been engaged in a joint research program in which samples of higher actinides were irradiated in the 600-MW Dounreay prototype fast reactor in Scotland. Three separate fuel pins (FPs) were prepared and irradiated. The actinides in FP-1 and FP-2 were irradiated for 63 full power days (FPD). The irradiation of FP-4 was carried out over a longer period (492 FPD) and should provide the best estimate for cross-section and fission-yield measurements made to date. This report presents the analytical results using mass spectrometry and radiometry for the actinides and the primary activation products for the three FPs. This report also details the fission-product yield measurements for samples of FP-4 by gamma-ray assay techniques with selected results from similar measurements previously obtained for FP-1 and FP-2 samples.
\end{abstract}




\section{INTRODUCTION}

The objective of the joint U.S.-U.K program has been to investigate the neutronic and irradiation behavior of higher actinides in fast reactors. This summary report details the analytical methodologies used to quantify the actinides after irradiation and presents results obtained for the reaction products for the three physics-specimen fuel pins (FPs). Each FP contained dosimeter materials to aid in flux calculations; these results are also presented.

The irradiations were carried out over a period of six years. The total exposure was 295,000 MWd consisting of 38,000 MWd (July 82-Sept. 83), 57,000 MWd (Dec. 85-May 86), 81,000 MWd (Aug. 86-Feb. 87), and 119,000 MWd (Sept. 87-July 88). The total fluence was $-2 \times 10^{23} \mathrm{n} / \mathrm{cm}^{2}$. A detailed reactor power history as it relates to the exposure of FP-4 will be described in a future report.

Isotopic and material concentration measurements of the target actinides and those created by the irradiations were performed for FP-1 in late 1984, for FP-2 from late 1986 to early 1987, and for FP-4 from mid 1990 to early 1992. (Additional cross checks and remeasurements of FP-4 samples continued up to early 1994.) The procedure involved, first, the cutting away of the outer pin cladding to free individual capsules, and next, the identification and complete dissolution of each capsule separately. These measurements were performed using mass spectrometry and/or radiometry (see Sect. 3 and Appendix A). Appendixes B and C present the summary data sheets for FP-1, FP-2, and FP-4.

Earlier Oak Ridge National Laboratory (ORNL) reports published in this effort detail the preparation of samples for irradiation, ${ }^{1}$ characterization of the actinide and dosimeter samples, ${ }^{2}$ the preanalysis calculations for FP-1, ${ }^{3}$ fission-product yield data, ${ }^{4}$ and analyses of samples in FP-1 and FP-2. 


\section{PHYSICS SPECIMEN MATERIALS AND DOSIMETERS IRRADIATED IN THE U.S-U.K. HIGHER ACTINIDE EXPERIMENT}

Twenty-one actinide materials were selected for use as physics specimens for the U.S.-U.K. actinide experiment. Table 1 shows the specimens and their enrichment before irradiation along with their positioning in the three FPs. The vanadium-encapsulated materials were loaded into each FP in five sections (see Fig. 1).

Table 1. Physics specimen materials selected for irradiation

\begin{tabular}{lllc}
\hline & & $\begin{array}{c}\text { Position in } \\
\text { FP }\end{array}$ & $\begin{array}{c}\text { Isotope enrichment } \\
\text { (wt \%) }\end{array}$ \\
\hline${ }^{248} \mathrm{Cm}$ & Batch No. & & \\
${ }^{246} \mathrm{Cm}$ & 1117 & 4 & 92.15 \\
${ }^{237} \mathrm{~Np}$ & C59SHIP & 5,6 & 66.53 \\
${ }^{244} \mathrm{Cm}$ & $24 \mathrm{HP}$ & 7 & 99.99 \\
${ }^{243} \mathrm{Cm}$ & C57CM46 & 8,9 & 92.35 \\
${ }^{238} \mathrm{U}$ & 1011 & 10 & 57.67 \\
${ }^{243} \mathrm{Am}$ & Q1 & 11 & 99.955 \\
${ }^{241} \mathrm{Am}$ & H1P1018 & 12,13 & 99.987 \\
${ }^{242} \mathrm{Pu}$ & $79 \mathrm{AMB} 4$ & 14,15 & 99.995 \\
${ }^{244} \mathrm{Pu}$ & $290 \mathrm{~A}$ & 16 & 97.96 \\
${ }^{240} \mathrm{Pu}$ & $297 \mathrm{C}$ & 20 & 87.69 \\
${ }^{239} \mathrm{Pu}$ & HIP1068 & 21,22 & 99.86 \\
${ }^{241} \mathrm{Pu}$ & $453 \mathrm{BO}$ & 23 & 99.10 \\
${ }^{232} \mathrm{Th}$ & $307 \mathrm{~A}$ & 24 & 96.77 \\
${ }^{236} \mathrm{U}$ & 4151 & 25 & 100.00 \\
${ }^{234} \mathrm{U}$ & $201 \mathrm{DMR}$ & 26 & 88.96 \\
${ }^{235} \mathrm{U}$ & M9 & 27 & 99.764 \\
${ }^{231} \mathrm{~Pa}$ & $264 \mathrm{C}$ & 28 & 99.89 \\
${ }^{238} \mathrm{Pu}$ & PaF1 & 29 & 100.00 \\
${ }^{230} \mathrm{Th}$ & $06 \mathrm{HP014}$ & 30 & 99.38 \\
${ }^{233} \mathrm{U}$ & $256 \mathrm{~A}$ & 31 & 89.39 \\
& $240 \mathrm{~A}$ & 32 & 99.886 \\
\hline & & & \\
\hline
\end{tabular}

Dosimeter materials were selected to help determine neutron fluxes; three positions were chosen to help determine axial fluctuations in flux level. Figure 1 shows the sample locations for dosimeters in the FPs; Table 2 shows the materials and their enrichments. Additional details are given in Refs. 1 and 2. 

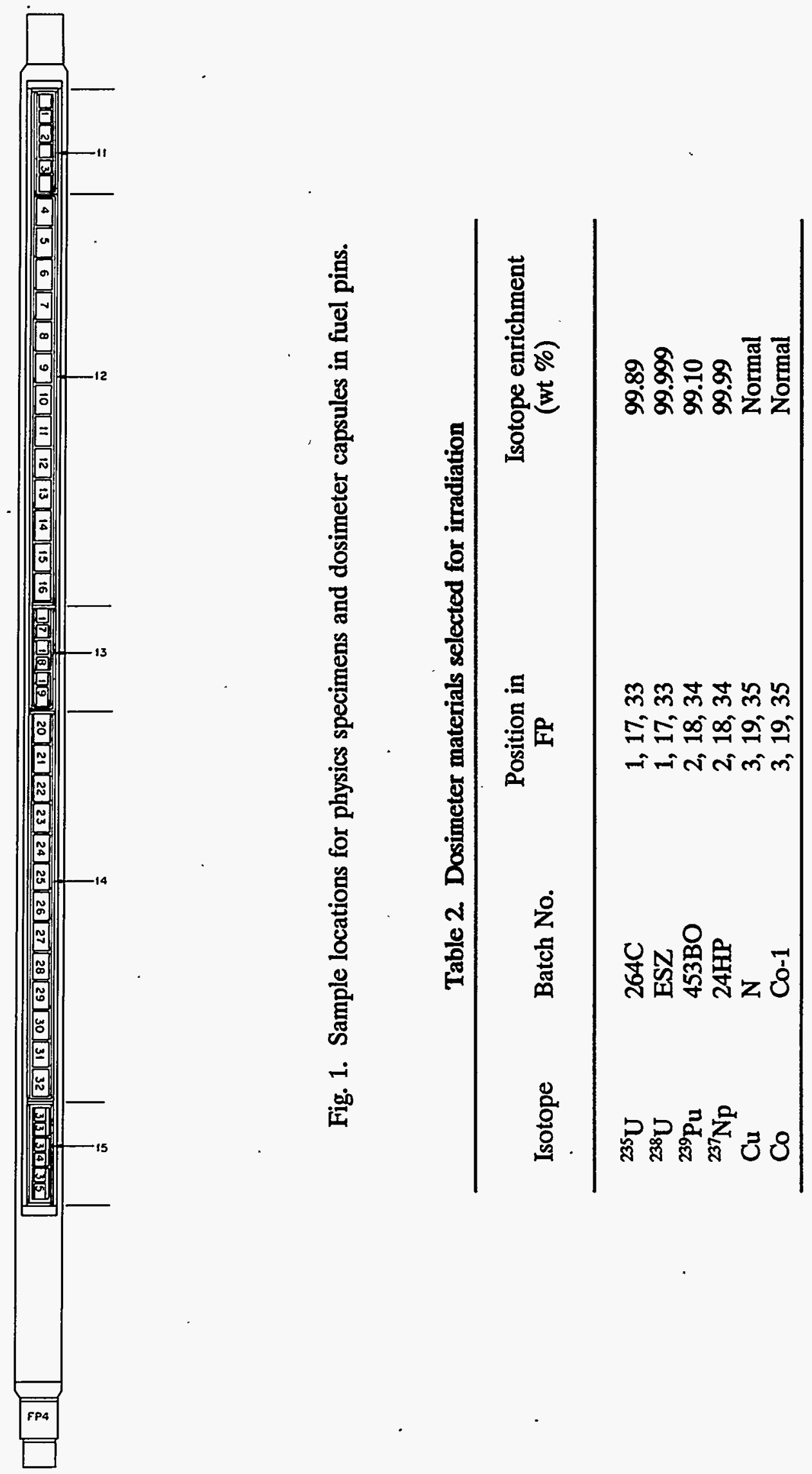


\section{METHODS USED FOR ACTINIDE ANALYSIS}

\subsection{INTRODUCTION}

A combination of high-sensitivity mass spectrometry and radiometric methods was used to analyze the various actinides and neutron reaction products. Milligram quantities or less of materials made accurate analyses very difficult. The removal and identification of each capsule without loss or damage were two of many very difficult operations, especially because these tasks must be accomplished in a hot cell. Another very difficult and time-consuming step was the dissolution of the materials in the hot cells after the materials were removed from the FPs. The dissolution methodology for the various materials is discussed in Sect. 3.2.

\subsection{DISSOLUTION OF ACTINIDE PHYSICS SPECIMENS AND DOSIMETER MATERIALS}

\section{Arrangement of FP Assembly}

For the U.S.-U.K. actinide experiment, FPs irradiated in the Dounreay prototype fast reactor (PFR), were comprised of five separate stainless steel tubes (see Fig. 1) in which various vanadium-encapsulated actinide materials were packaged as described in Ref. 1 . Three of the tubes contained dosimeter material (six samples per tube) for measurement of the neutron flux to which the assembly was exposed. The remaining two tubes contained the actinide physics specimens. These were packaged 13 samples per tube (see Fig. 1). The tubes then were placed in a stainless steel jacket and arranged such that each physics specimen tube was bracketed on each end by a dosimeter package. All the stainless steel tubes were crimped at both ends to prevent movement of the individual specimens within them.

\subsubsection{Removal and Identification of Specimens and Dosimeters}

Prior to shipment to the hot-cell facility (where the isolation and dissolution of the individual specimens were performed) the inner stainless steel jacket was removed from the FP and cut into two sections to facilitate shipping. Individual specimens were approximately $1 \mathrm{~cm}$ in length; a unique dot code was imprinted on the side near the base of each capsule (see Ref. 2). The physics specimens from the opened tube were removed by simply pouring them out. The remaining four tubes were removed from the jacket by cutting portions of the jacket away until the tubes were exposed; then the tubes were pulled out with pliers. The individual specimens were removed from the stainless steel tubes by mechanically opening both ends of the tube and then pushing the specimens through the opening with a rod. Some difficulty was encountered at this stage because of swelling of the individual specimens.

An in-cell Kollmorgen periscope at 20X magnification was used to examine each capsule and to identify the capsules by the dot codes imprinted on them. All 35 capsules were recovered from the FP without visual damage. After each capsule had been visually examined and identified, it was stored in a clean glass bottle. 


\subsection{Reagents and Glassware}

Nitric acid, hydrofluoric acid, and hydrochloric acid used during the dissolution steps were Ultrex-grade (equivalent to double distilled). Water used for dilutions was obtained by passing distilled water through an ion-exchange column filled with mixed anion and cation resins and then by redistilling this product with a quartz still. New glassware (quartz for steps involving hydrofluoric acid) was used for each dissolution. Prior to use, all glassware was soaked overnight in $8 \mathrm{~N}$ nitric acid. Upon removal from the acid bath, the glassware was rinsed first with distilled water and then a high-purity water and allowed to dry. Plastic reagent bottles were rinsed with nitric acid, distilled water, high-purity water, and reagentgrade ethanol and allowed to dry prior to. use.

\subsubsection{Summary of Techniques Used for-Dissolution of Physics Specimens}

All dissolutions of the actinide specimens were performed in a radiochemical hot cell. Dissolutions were performed in a 50 -mL quartz beaker equipped with a quartz watchglass and quartz boiling chips. Each capsule was rinsed with acetone before dissolution was started to remove any external contamination. Dissolution of the individual capsules was begun by adding $5 \mathrm{~mL}$ of $8 \mathrm{~N}$ nitric acid to dissolve the vanadium encapsulation material. No heat was used during this step. Dissolution of the vanadium began immediately, as was evidenced by the generation of gas bubbles, and was completed within $1 \mathrm{~h}$. At this point, the solution was blue, and the actinide material rested on the bottom of the beaker in a single rod-shaped segment.

After dissolution of the vanadium, the majority of the solution was transferred to another beaker while the actinide material was undergoing dissolution. Heat was provided to the solution by a hotplate and kept at a temperature at which vapor condensed on the watchglass-but below the solution boiling point. Additional acid was added to the quartz beaker during the dissolution, as needed, to maintain a solution volume of about 10 to $15 \mathrm{~mL}$. The time required to complete the dissolution of a sample varied from $2 \mathrm{~h}$ to 2 weeks. Dissolution was termed complete if no solid material could be observed when the beaker was placed on a white background and viewed with a telescope and mirror arrangement.

After the actinide material was dissolved, the vanadium-containing solution was transferred back to the beaker containing the dissolved actinide, and the total volume was reduced to about 10 to $15 \mathrm{~mL}$. The solution was cooled, transferred quantitatively to a tared 25 -mL volumetric flask, brought to $25 \mathrm{~mL}$ with $8 \mathrm{~N}$ nitric acid, and weighed. For long-term storage, the solutions were transferred to acid-leached, glass, screw-capped bottles.

Dissolution of the uranium and curium specimens was relatively easy. It was completed in a period ranging from several hours to several days. Only nitric acid and heat were used to dissolve the material.

Dissolution of americium, plutonium, and thorium specimens was difficult, taking up to 2 weeks to put some specimens in solution. Nitric acid, hydrofluoric acid, and heat were used to dissolve the actinide material. Hydrochloric acid was added to several of the plutonium and thorium dissolutions in an attempt to increase the speed of dissolution. However, the addition of hydrofluoric acid produced no observable improvement in the dissolution rate.

Dissolution of neptunium and protactinium specimens from FP-1 and FP-2 took several days. To dissolve the FP-4 specimens in less time, they were subjected to a mixture 
of nitric acid and hydrofluoric acid on removal of the vanadium-containing solution. This procedure resulted in complete dissolution of the samples with no problems.

\subsection{Problems Causing Loss of Sample}

Leaving the vanadium-containing solution in the original beaker presented problems when the solution volume reached a level low enough such that a vanadium precipitate formed. In the presence of this precipitate, the solution would "bump" vigorously, resulting in the loss of a portion of the sample. Several samples were compromised because of this phenomenon. A second problem with bumping occurred when the dissolution lasted more than a few days. In these samples the sudden generation of a single, large air bubble would occur when the samples became too hot. Even with quartz boiling chips present, the bumping that occurred resulted in the loss of portions of at least four samples. The addition of fresh boiling chips to the beaker did not alleviate the problem. The control of the amount of heat provided to the solution was critical to the effectiveness of the dissolutions and required constant monitoring by a technician. One sample was lost when the beaker in which it was being dissolved was inadvertently overturned.

\subsubsection{Dissolution of Dosimeters}

The dissolution of the dosimeter specimens, especially from FP-4, presented a unique problem. Within each vanadium capsule were two individual samples which, preferably, would be separated prior to dissolution. Because of the small size of the vanadium pin, it was necessary to remove the sample from the hot cell prior to cutting the sample open, because the manipulator arms used in the hot cell do not provide the dexterity required for this delicate operation. With the ends of the capsule removed, the two samples from FP-1 and FP-2 were pushed out and separated. Dissolution was performed in a radiochemical hood similar to that used on the physics specimens. However, the dosimeter specimens from FP-4 gave radiation readings (i.e., beta/gamma) above that allowed for glove-box operation. It is for this requirement that the dosimeter pairs were dissolved together (see Appendix C).

\subsection{DESCRIPTION OF MASS SPECTROMETER USED FOR ACTINIDES ANALYSIS}

The limited quantities of the samples for irradiation required that sensitive methods be used for measurements. A combination of high-sensitivity mass spectrometry and radiometric methods generally met these requirements (see Appendix A).

The mass spectrometer used in this work is of the "KAPL" configuration consisting of double deflection magnets. Described in a Knolls Atomic Power Laboratory paper, ${ }^{6}$ it possesses ion-counting capability for isotopic composition and isotope dilution measurements. The ions are magnetically deflected through $90^{\circ}$ on a $30-\mathrm{cm}$ radius. Ions are detected with an electron multiplier (currently using Hamamatsu Type R515), amplified, and stored on a disk as pulses. The stored information is transferred to a Micro-VAX system for calculation and data processing. ${ }^{7}$ A slit midway between the magnets allows only a single mass to be admitted to the second stage. This process results in a spectrum that at high mass is very clean and free from scattered ions. The magnetic field is about 0.8 tesla across a gap of 14.5 $\mathrm{mm}$. The accelerating voltage for this field and the mass region for the actinides is approximately $8 \mathrm{kV}$. The vacuum system is all metal except for the glass that covers the 
source housing. The source region is evacuated using a cryogenic pump; the rest of the system (isolated by a valve) is evacuated with ion pumps. Figures 2 and 3 show the mass spectrometer and its associated electronics.

The preparation of samples for loading into the instrument is accomplished using the resin-bead technique., ${ }^{8,9}$ For elements that adsorb on anion resin (e.g., $\mathrm{Th}, \mathrm{Pu}$, and $\mathrm{U}$ ), a solution of the element, adjusted to $8 \mathrm{M}$ in $\mathrm{HNO}_{3}$ is contacted with about ten resin beads. These are washed with $8 \mathrm{MHNO}_{3}$, and a single resin bead is isolated and transferred to the single, zone-refined rhenium filament for isotopic analysis. Trivalent elements that do not adsorb on anion resin under these conditions are purified by solvent extraction and loaded from a weak acid solution onto cation beads (these include americium and curium). The resin-bead loading technique has several advantages: (1) better control of radioactivity in the mass spectrometer and sample introduction area; (2) improved ion optics from the point source; and (3) greater ionization efficiency that allows for more stable ion signals and, hence, better precision of measurement.

For any actinide, spectrum scanning and data recording consist of taking the horizontal sweep voltage from a sweep controller and applying it in series with the accelerating voltage. The sweep voltage is a stair-step function that successively gates the memory channels of the sweep controller. The voltage is thus swept in synchronism with the channel gating so that counts occurring at a given voltage are stored in the same channel during each sweep across the mass spectrum. Any mass in the spectrum can be scanned a predetermined number of times for each traversal of the entire mass range. This procedure allows the scanning scheme to be optimized for the requirements of a given actinide.

For any particular analysis, the counting rate for the major isotope is kept, if possible, at $2 \times 10^{5}$ to $3 \times 10^{5}$ counts/s to avoid a high "count loss" correction. A bias correction is also required because the accelerating voltage is swept, and fractionation effects are inherent in thermal ionization methods. The count loss or system dead-time correction and bias correction are determined by measuring the composition of National Institute of Standards and Technology SRM-U500 standard reference material (SRM). From the observed ratios the bias correction required per mass unit and the system dead time are calculated. Because the elements being measured do not differ drastically in mass from uranium, the corrections are assumed to apply. After the corrections are established, analyses of standards are carried out for quality control purposes.

The system is checked for instrument stability and calibration by running controls using either uranium and/or plutonium certified isotopic standards. These controls are analyzed under the same conditions as are samples. All are on resin beads. Isotopic results given in Table 3 are typical for a mixture of SRM-947 and SRM-500 standards. These results indicate that precisions of $\pm 0.5 \%$ (for minor isotopes) and $\pm 0.1 \%$ (for major isotopes) are obtained in the $1 \%$ and 50 to $99 \%$ concentration ranges, respectively. 


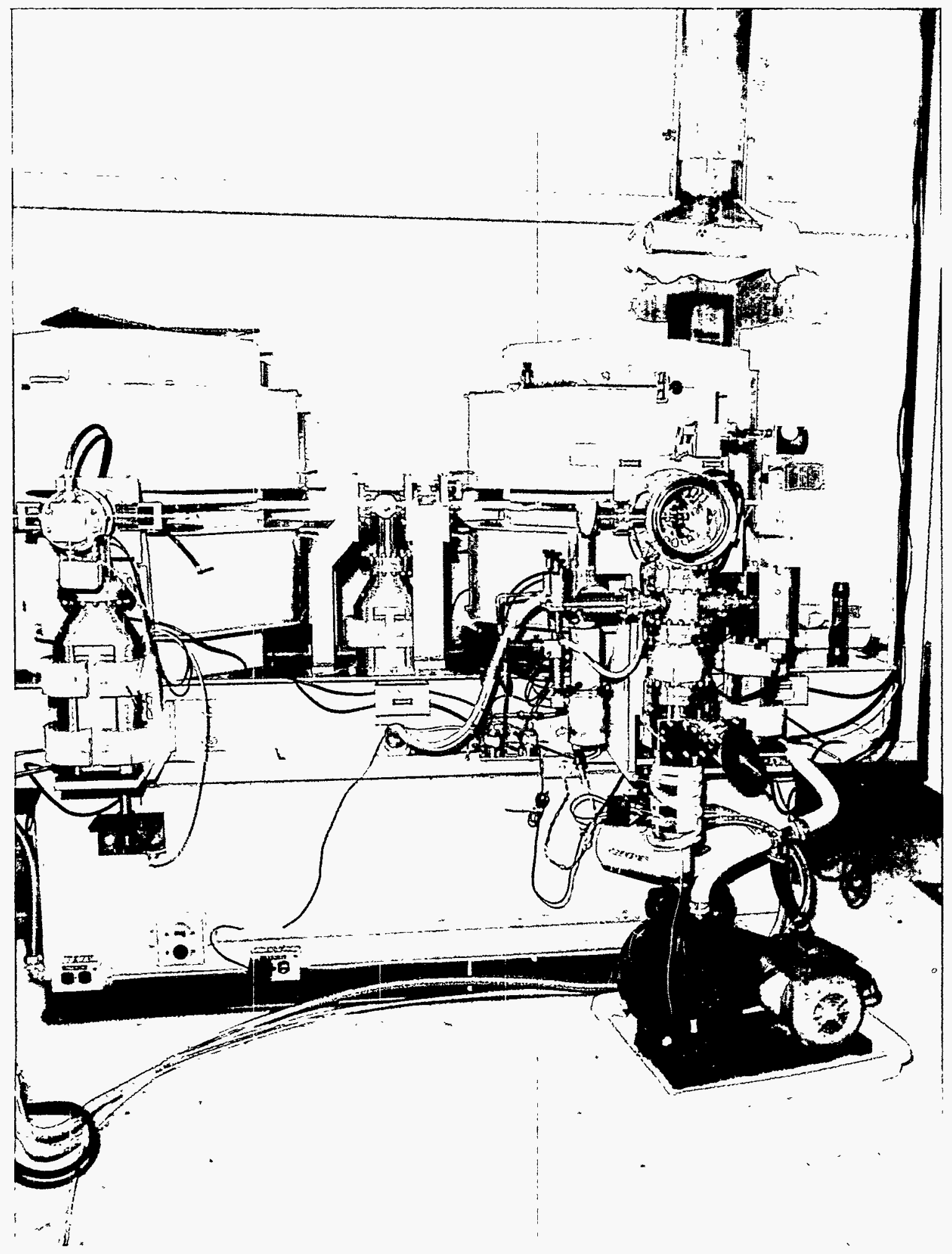

Figure 2. Mass spectrometer for analysis of actinides 


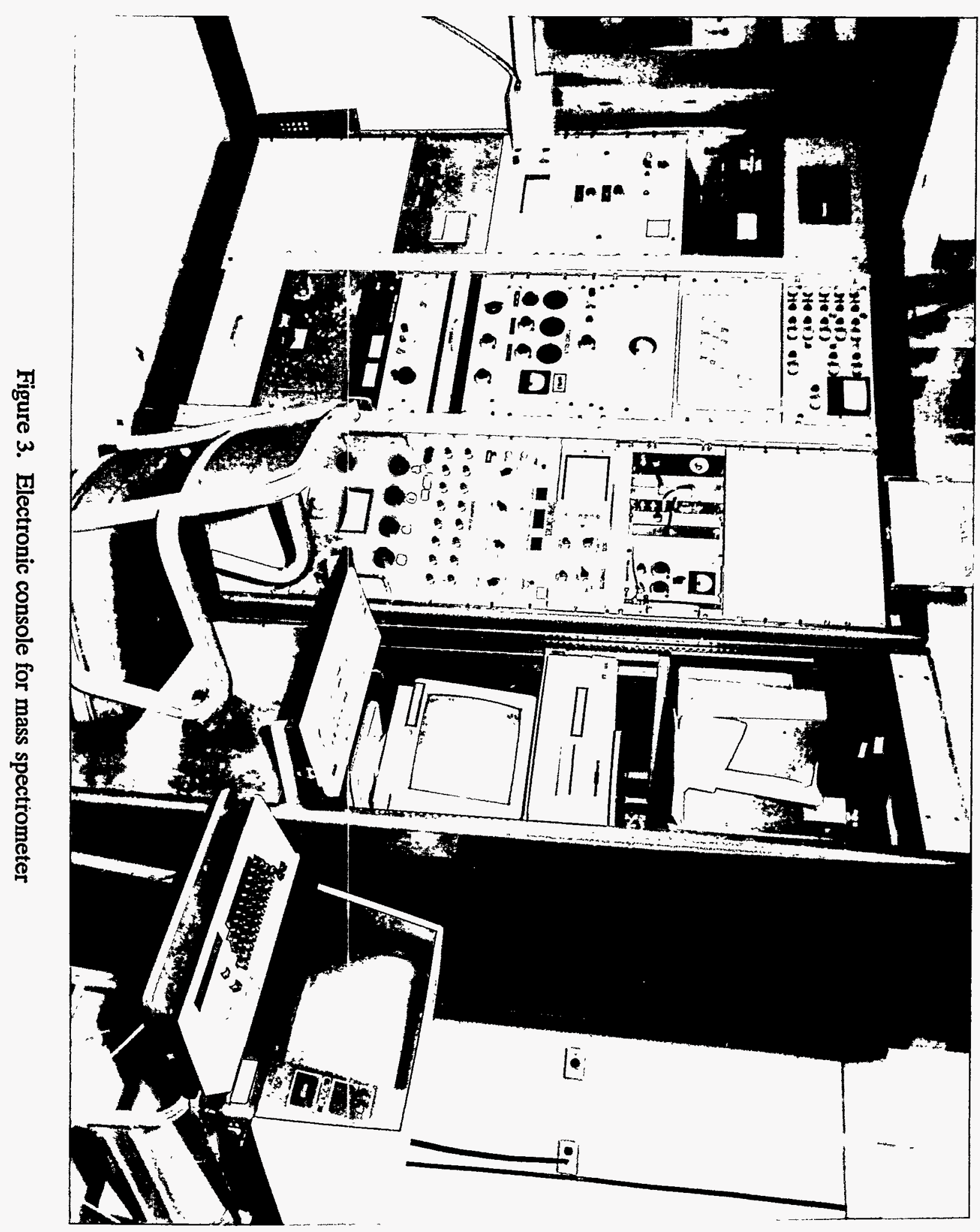


Table 3. Mixed plutonium and uranium standards on resin beads ${ }^{a}$

\begin{tabular}{lrrrr}
\hline & \multicolumn{4}{c}{ SRM-947 plutonium } \\
& $238 / 239$ & $240 / 239$ & $241 / 239$ & $242 / 239$ \\
\cline { 2 - 4 } NIST $^{b}$ & 0.00370 & 0.24147 & 0.04309 & 0.01559 \\
ORNL $^{c}$ & 0.00371 & 0.24156 & 0.04281 & 0.01559 \\
Std. dev. & \pm 0.00002 & \pm 0.00057 & \pm 0.00025 & \pm 0.00008 \\
& \multicolumn{4}{c}{ SRM-500 uranium } \\
\\
NIST & $234 / 235$ & $235 / 238$ & $236 / 235$ & \\
ORNL & 0.01042 & 0.99971 & 0.001519 & \\
Std. dev. & 0.01034 & 0.99851 & 0.001522 & \\
\hline & \pm 0.00005 & \pm 0.00209 & \pm 0.000005 & \\
\hline
\end{tabular}

${ }^{a}$ Nine analyses run over a 2 -month period.

${ }^{b}$ National Institute of Standards and Technology.

${ }^{\circ}$ Oak Ridge National Laboratory.

\subsection{DESCRIPTION OF RADIOMETRIC METHODS USED FOR ACTINIDE ANALYSIS}

\subsubsection{Plutonium-238}

Plutonium-238, with a half-life of 87 years, comprises a very small fraction of the material in these samples and cannot usually be analyzed by mass spectrometry because of the interference of ${ }^{238} \mathrm{U}$. Aliquots of the solution from the dissolution described in Sect. 3.2.4 are diluted to $1 \mathrm{M} \mathrm{HNO}_{3}$, and the plutonium valence is adjusted to the tetravalent state with hydroxylamine hydrochloride and sodium nitrite. Residual fluoride is complexed with aluminum. $\mathrm{Pu}^{4+}$ is extracted into $0.5 \mathrm{M}$ thenoyltrifluoroacetone (TTA) in xylene. For counting the alpha activity on a gas-flow proportional ( $2 \pi$ geometry) counter, aliquots of the organic phase are evaporated onto polished stainless steel planchets. The alpha pulse-height distribution on these plates is measured on a surface barrier detector coupled with a multichannel analyzer. Enough counts are collected to give at least 1000 counts in the 5.49-MeV peak of ${ }^{238} \mathrm{Pu}$. The total alpha count, percent of ${ }^{238} \mathrm{Pu}$ alpha, sample weight, and dilution factor are used to calculate the ${ }^{238} \mathrm{Pu}$ concentration.

\subsubsection{Americium and Curium}

Aliquots of the solution from the dissolution (or of appropriate dilutions) are evaporated onto stainless steel planchets, and the gross alpha activity is measured by gas-flow proportional counting. Alpha pulse-height counting gives the ratios of ${ }^{243} \mathrm{Am}(5.27 \mathrm{MeV})$, ${ }^{241} \mathrm{Am}(5.48 \mathrm{MeV})$, and ${ }^{244} \mathrm{Cm}(5.81 \mathrm{MeV})$. The amount of each nuclide can be calculated from the gross alpha activity and their respective specific activities. Measurement of the 60- 
$\mathrm{keV}$ gamma from ${ }^{241} \mathrm{Am}$ using a $\mathrm{Ge}(\mathrm{Li})$ detector coupled with a multichannel analyzer gives a further check on the ${ }^{241}$ Am content.

\subsubsection{Neptunium-237}

Aliquots of the dissolved sample are spiked with known amounts of ${ }^{239} \mathrm{~Np}$ tracer and are treated with $\mathrm{K}_{2} \mathrm{Cr}_{2} \mathrm{O}_{7}$ to oxidize neptunium (and plutonium) to the hexavalent state. The sample is adjusted to $2 \mathrm{M} \mathrm{Al}\left(\mathrm{NO}_{3}\right)_{3}$, and the neptunium is extracted (along with plutonium and uranium) into hexone. The neptunium and plutonium are stripped from the organic phase into a reducing solution containing $\mathrm{FeCl}_{2}$ in $1 \mathrm{M} \mathrm{HCl}$. The reduced neptunium is then extracted into $0.5 \mathrm{M}$ TTA, while the $\mathrm{Pu}^{3+}$ remains in the aqueous phase. Aliquots of the organic phase are plated and counted for alpha activity as previously described. Alpha pulseheight analysis is again used to determine the amount of $4.78-\mathrm{MeV}{ }^{237} \mathrm{~Np}$ as well as any plutonium carryover. To determine the efficiency of neptunium recovery, an aliquot of the TTA phase is counted for ${ }^{239} \mathrm{~Np}$ gamma. The alpha activity of ${ }^{237} \mathrm{~Np}$ is corrected for the recovery.

\subsubsection{Protactinium-231}

Samples for protactinium analysis must be kept in at least $4 M \mathrm{HCL}$ solutions. An aliquot of this solution is adjusted to $6 \mathrm{M} \mathrm{HCl}$ and contacted with di-isobutyl carbinol (DIBC) to extract the protactinium. The organic phase is scrubbed with $6 \mathrm{M} \mathrm{HCl}$, and aliquots of the DIBC are evaporated onto tantalum planchets and counted for alpha activity. Purity of the protactinium fraction (5.01 MeV) is checked by pulse-height analysis. Because the gamma tracer, ${ }^{233} \mathrm{~Pa}$, is not readily available, recovery estimates are based on analysis of protactinium solutions of known concentration.

\subsubsection{Uranium-232}

Uranium is separated from other radioelements by anion exchange. Uranium in $6 M$ $\mathrm{HCl}$ is adsorbed on the resin and washed with $\mathrm{HCl}$ to remove $\mathrm{Th}, \mathrm{Am}, \mathrm{Cm}, \mathrm{Pu}$, and $\mathrm{Np}$. Elution with dilute $(0.01 M) \mathrm{HCl}$ gives a purified uranium solution for alpha pulse-height analysis. The 5.32- $\mathrm{MeV}^{232} \mathrm{U}$ and $4.82-\mathrm{MeV}^{233} \mathrm{U}$ alpha peaks are integrated, and the ratio of ${ }^{232} \mathrm{U}$ to ${ }^{233} \mathrm{U}$ is determined. 


\section{RESULTS AND DISCUSSION OF ACTINIDE ANALYSIS}

Appendixes B and C contain sample data for each target isotope material that is listed at the top of each page. The information given for each target isotope is broken down into three parts: (A) Part A contains the isotopic composition (in atoms \%) of the element with the highest available isotope enrichment of the target isotope as described in Refs. 1 and 2. Isotopic analysis and dates of measurement are shown for FP-1, FP-2, and FP-4 after irradiation under separate column headings. (B) Part B indicates the estimated weight of the target isotope that was encapsulated in vanadium before its fabrication into pins. The measured weight of the target isotope after irradiation and the dates for measurement are given under the appropriate headings for FP-1, FP-2, and FP-4 when reading from top to bottom of the page. (C) Part $\mathrm{C}$ contains isotopic and concentration data for important nuclear reaction products when present in sufficient quantity to be measured by currently available techniques.

Results for concentration have been obtained using isotope dilution mass spectrometry and radiochemical counting methods. Isotopic composition results are generally of high quality and were shown to be very reproducible when replicates were analyzed. Although agreement between measured and expected concentration values in the majority of results appears good, the difference in some is much greater than would be expected and lies outside the proven performance of the methods employed. The difference and large variance are disturbing for some results and could be caused by errors resulting from conditions not easily controlled (e.g., target loading and encapsulation, starting material stoichiometry, weighing, dissolution, contamination in hot cells or glove boxes, and aliquoting). Error bars have not been assigned to results because of the uncertainties. However, overall errors on concentration values are estimated between $3 \%$ and $5 \%$ when optimum measurable quantities could be taken. These would include isotopes of $\mathrm{U}, \mathrm{Pu}, \mathrm{Am}$, and Th. Other more difficult analyses (involving counting methods where isotopes of interest were minor contributors of the total counts because of differing half-lives) could be performed only on a best-effort basis. These may include isotopes of $\mathrm{Am}, \mathrm{Np}, \mathrm{Cm}, \mathrm{Pa}$, and $\mathrm{Pu}$.

We have made a preliminary comparison of experimental results with calculations using the most recently available cross-section data (ENDF/B-VI). A total of 26 samples for 21 actinides were present in FP-4 (see Table 1). Sample No. $8\left({ }^{244} \mathrm{Cm}\right.$ ) was lost during dissolution. We had direct evidence that substantial portions of samples No. $32\left({ }^{233} \mathrm{U}\right)$, No. 11 $\left({ }^{238} \mathrm{U}\right)$, and No. $23\left({ }^{239} \mathrm{Pu}\right)$ were lost during dissolution. For 18 of the remaining 22 samples (14 actinides), the calculated concentrations of the principal actinides were within $15 \%$ of the measured values. This comparison also showed that some sample loss probably occurred also for samples No. $29\left({ }^{231} \mathrm{~Pa}\right)$, No. $26\left({ }^{236} \mathrm{U}\right)$, No. $30\left({ }^{238} \mathrm{Pu}\right)$, and No. $16\left({ }^{242} \mathrm{Pu}\right)$. These uncertainties clearly outweigh all other uncertainties in the measurements. 


\section{GAMMA-RAY ASSAY MEASUREMENTS OF FP-4 SAMPLES FOR FISSION PRODUCT YIELDS}

In this section we discuss the experimental details for FP-4; these are quite similar to our previous reports for the samples in FP-1 ${ }^{4}$ and FP-2.

Preparation of the actinide samples for the gamma-ray assay measurements followed standard chemical procedures as described in Sect. 3.2, and an aliquot from each actinide sample was extracted for sample preparation. For 12 of the actinide samples, the extracted aliquot was dried on a flat surface of 0.02 -mm-thick clear plastic affixed to a $0.9-\mathrm{mm}$-thick aluminum plate having a $2.54-\mathrm{cm}$-diam centered hole. The aliquot was dried and then covered with a similar clear plastic to fix the sample material in the center hole. For these samples, then, unlike the liquid samples of FP-1 ${ }^{4}$ and FP-2, ${ }^{5}$ corrections for gamma-ray -attenuation by the liquid and bottle were eliminated. However, the aliquot size was determined by the alpha activity of the aliquot, which, in turn, determined the aliquot obtained for these measurements. For the remaining actinides, the alpha intensity was too large for fabrication as a dried sample with a sufficient aliquot to do the gamma-ray assay measurements. For these 13 samples, the aliquot amount was determined by requiring that the dose for a given liquid sample be less than $40 \mathrm{mR} / \mathrm{h}$. The bottles used were smaller than those used for FP-1 and FP-2 samples, and the aliquot for each sample was diluted to a volume of $0.5 \mathrm{cc}$. For these samples, a special sample holder was fabricated to hold the sample upright and at a predetermined distance from the gamma-ray detector. The given initial sample (isotopic) masses, ${ }^{2}$ the present aliquots, and the sample configuration (dried solid or liquid) are tabulated in Table 4.

In addition to the actinide samples, 11 samples containing aliquots of dosimeters were obtained and counted. These included separated samples for the cobalt-copper dosimeters (six samples in all) assayed for ${ }^{60} \mathrm{Co}$, three samples that combined the ${ }^{237} \mathrm{~Np}$ and ${ }^{239} \mathrm{Pu}$ dosimeters assayed for ${ }^{137} \mathrm{Cs}$, and two (of the original three) samples that combined the ${ }^{235} \mathrm{U}$ and ${ }^{238} \mathrm{U}$ dosimeters also assayed for ${ }^{137} \mathrm{Cs}$.

The aliquots were counted using two germanium detector systems, one a $15 \%$ efficiency $\mathrm{Ge}(\mathrm{Li})$ detector having a resolution full width at half maximum (FWHM) of $\sim 2.1$ $\mathrm{keV}$ for $E_{\gamma}=1.33 \mathrm{MeV}$. This one was used for measurement of gamma rays having energies between 0.1 and $3 \mathrm{MeV}$, and the other, a small planar detector having a resolution FWHM of $\sim 0.5 \mathrm{keV}$ for $E_{\gamma}=122 \mathrm{keV}$, was used for measurement of gamma rays having energies between 10 and $400 \mathrm{keV}$. The latter detector also detected beta rays emanating from the dried samples; thus some of the measurements with these samples included a 3.2-g/cc carbon absorber placed between the sample and the detector. Gamma-ray attenuation by the carbon absorber was corrected using the absorption tables of Storm and Israel. ${ }^{10}$ For the liquid samples, attenuation through the bottom of the glass bottle and by the liquid was also computed.

For each of the actinide samples, at least one spectrum was obtained using each detector. Measurements were initiated in March 1990 (about 600 days following the end of the irradiation of the fuel pin) and essentially were completed in May 1990; two additional spectra were obtained in 1992 to help clarify ambiguous results obtained during the 1990 measurements. Data reduction was accomplished using the documented code TPASS ${ }^{11}$ combined with manual methods when required. Computed peak yields were corrected for detector efficiency and (if needed) absorption; peak energies were then compared with 
Table 4. FP-4 principal actinide masses

\begin{tabular}{lcccl}
\hline $\begin{array}{l}\text { Principal } \\
\text { isotope }\end{array}$ & $\begin{array}{c}\text { Sample } \\
\text { No. }\end{array}$ & $\begin{array}{c}\text { Total isotopic } \\
\text { mass (mg) }\end{array}$ & $\begin{array}{c}\text { y-ray assay } \\
\text { aliquot }(\%)\end{array}$ & $\begin{array}{l}\text { Sample } \\
\text { status }\end{array}$ \\
\hline${ }^{230} \mathrm{Th}$ & 31 & 2.883 & 1.00 & Solid \\
${ }^{232} \mathrm{Th}$ & 25 & 18.880 & 1.00 & Solid \\
${ }^{231} \mathrm{~Pa}$ & 29 & 2.512 & 0.10 & Solid \\
${ }^{233} \mathrm{U}$ & 32 & 7.652 & 0.30 & Solid \\
${ }^{234} \mathrm{U}$ & 27 & 3.500 & 1.00 & Solid \\
${ }^{235} \mathrm{U}$ & 28 & 8.373 & 0.40 & Solid \\
${ }^{236 \mathrm{U}}$ & 26 & 7.962 & 1.00 & Solid \\
${ }^{238} \mathrm{U}$ & 11 & 9.810 & 2.00 & Solid \\
${ }^{237} \mathrm{~Np}$ & 7 & 12.216 & 1.00 & Solid \\
${ }^{238} \mathrm{Pu}$ & 30 & $2.889^{b}$ & 2.00 & Liquid \\
${ }^{239} \mathrm{Pu}$ & 23 & 8.470 & 0.30 & Liquid \\
${ }^{240} \mathrm{Pu}$ & 21 & 10.839 & 0.60 & Liquid \\
${ }^{240} \mathrm{Pu}$ & 22 & 10.816 & 0.80 & Liquid \\
${ }^{241} \mathrm{Pu}$ & 24 & $4.136^{b}$ & 0.40 & Liquid \\
${ }^{242} \mathrm{Pu}$ & 16 & 2.046 & 2.00 & Solid \\
${ }^{244} \mathrm{Pu}$ & 20 & 2.108 & 2.00 & Solid \\
${ }^{241} \mathrm{Am}$ & 14 & 9.422 & 0.20 & Liquid \\
${ }^{241} \mathrm{Am}$ & 15 & 9.525 & 0.40 & Liquid \\
${ }^{243} \mathrm{Am}$ & 12 & 9.831 & 0.20 & Liquid \\
${ }^{243} \mathrm{Am}$ & 13 & 9.801 & 0.40 & Liquid \\
${ }^{243} \mathrm{Cm}$ & 10 & $0.373^{b}$ & 0.10 & Liquid \\
${ }^{244} \mathrm{Cm}$ & 9 & $7.940^{b}$ & 0.60 & Liquid \\
${ }^{246} \mathrm{Cm}$ & 5 & 6.691 & 0.20 & Liquid \\
${ }^{246} \mathrm{Cm}$ & 6 & 6.797 & 1.00 & Liquid \\
${ }^{248} \mathrm{Cm}$ & 4 & 1.765 & 1.00 & Solid \\
\hline${ }^{24}$ & & & \\
\hline
\end{tabular}

${ }^{a}$ From Table 5 of Ref. 2

${ }^{b}$ Recomputed as of July $17,1982$.

nuclear data for specific radionuclides to determine the number of atoms in the aliquot as of the end of the irradiation (EOI), which was taken to be July 7, 1988. The nuclear data ${ }^{1213}$ for the fission products studied in this analysis are given in Table 5. Uncertainties associated with half-lives were not propagated in the computations; however, uncertainties in branching ratios were included in the final uncertainty determinations. Particular interest was centered on the production of the "shielded" radionuclides ${ }^{110 m} \mathrm{Ag},{ }^{134} \mathrm{Cs},{ }^{152} \mathrm{Eu}$, and ${ }^{154} \mathrm{Eu}$. Other longer-lived fission product yields were also determined. Results for ${ }^{137} \mathrm{Cs}$ are given in Table 6; these results are compared with similar data deduced for the measurements of FP-2. To zero-order, the ratios of the ${ }^{137} \mathrm{Cs}$ yields for the actinides of FP-4 to those for FP-2 ought 
to be -8 based on the ratio of total irradiation of the FP-4 in the PFR with respect to the FP-2. The observed variations give some indication of the effects of the long irradiation (e.g., the "growing in" of ${ }^{233} \mathrm{U}$ in the ${ }^{232} \mathrm{Th}$ sample by capture, which increases the ${ }^{137} \mathrm{Cs}$ production because ${ }^{233} U$ has a much larger fission cross section than does ${ }^{232} \mathrm{Th}$ ). Yields for four other longer-lived fission products are given in Table 7, and yields for the "shielded" radionuclides are presented in Table 8.

In addition, the data were studied to obtain yields of long-lived actinides in the samples. Of particular interest, based on the FP-1 experience, were the yields of principal actinides that could be deduced directly from gamma-ray assay. These are presented in Table 9 in the fourth column. For comparison, values estimated from the radiometric results of Sect. 3.4 are given in the final column. These were deduced from data given in Appendix $\mathrm{B}$ as follows: in the table for ${ }^{238} \mathrm{Pu}$, capsule position 30, in the last column for (FP-4) the concentration after irradiation is reported as $0.65 \mathrm{mg}$ as of March 26,1990 . The $\gamma$-ray assay aliquot for this sample was $2.0 \%$. Therefore, the radiometric ${ }^{238} \mathrm{Pu}$ concentration to be compared with the $\gamma$-ray assay concentration should be $2 \%$ of $0.65 \mathrm{mg}$, or $13 \mu \mathrm{g}$. Similar values for the other six samples in Table 9 were also deduced. A 5\% uncertainty to these masses was assigned based on the discussion in Sect. 4. The $\gamma$-ray assay measurements tend to be smaller than the radiometric estimates by $\sim 12 \%$ on the average. Two potential sources of error in the gamma-ray assay are (a) the exact determination of the masses of the small aliquots and (b) the exact determination of the detection efficiencies including photon attenuations by the glass bottles. The relative actinide mass yields are excellent, and an uncertainty of $10 \%$ assigned to these data would be reasonable.

Actinides produced by means of neutron capture by the principal actinides, or else the beta-decay products of the radionuclides produced by capture, are given in Table 10. Finally, in Table 11 are given yields of other actinides observed and delineated in the various spectra. Some of these actinides (e.g., ${ }^{28} \mathrm{Th}$ ) were likely present in some of the samples before the irradiation started, while others were created by neutron interactions with nonprincipal (or minor) actinides in the samples. Lastly, the results of the dosimeter studies are given in Table 12. 
Table 5. Nuclear data for fission products

\begin{tabular}{|c|c|c|c|}
\hline \multirow[b]{2}{*}{ Radionuclide } & \multirow[b]{2}{*}{ Half-life } & \multicolumn{2}{|c|}{ Gamma ray } \\
\hline & & $\begin{array}{l}\text { Energy } \\
\text { (keV) }\end{array}$ & Branching (\%) \\
\hline${ }^{106} \mathbf{R h}^{a}$ & $366.9 \mathrm{~d}$ & $\begin{array}{r}621.8 \\
1050.1\end{array}$ & $\begin{array}{l}9.95 \bullet 0.75 \\
1.45 \pm 0.10\end{array}$ \\
\hline${ }^{110 m} \mathrm{Ag}^{b}$ & 252. d & $\begin{array}{r}884.2 \\
937.4 \\
1383.9\end{array}$ & $\begin{array}{l}72.6 \pm 0.3 \\
34.2 \pm 0.3 \\
24.3 \pm 0.2\end{array}$ \\
\hline${ }^{125} \mathrm{Sb}$ & $2.758 \mathrm{y}$ & $\begin{array}{l}427.89^{c} \\
600.56 \\
635.90 \\
463.38\end{array}$ & $\begin{array}{l}29.44 \pm 0.99 \\
17.78 \pm 0.95 \\
11.32 \pm 0.68 \\
10.45 \pm 0.57\end{array}$ \\
\hline${ }^{134} \mathrm{Cs}$ & $2.066 \mathrm{y}$ & $\begin{array}{l}604.74 \\
795.80\end{array}$ & $\begin{array}{l}98.6 \pm 0.3 \\
87.8 \pm 1.4\end{array}$ \\
\hline${ }^{137} \mathrm{Cs}$ & $30.14 y$ & $661.64^{d}$ & $86.0 \pm 0.6^{d}$ \\
\hline${ }^{144} \mathrm{Ce}$ & $284.7 d$ & 133.53 & $11.09 \pm 0.20$ \\
\hline${ }^{144} \mathrm{Pr}^{\mathrm{e}}$ & $284.7 \mathrm{~d}$ & $\begin{array}{r}696.48 \\
2185.78\end{array}$ & $\begin{array}{l}1.34 \pm 0.02 \\
0.74 \pm 0.03\end{array}$ \\
\hline${ }^{152} \mathbf{E u}$ & $13.6 \mathrm{y}$ & 1407.92 & $20.7 \bullet 0.7$ \\
\hline${ }^{154} \mathrm{Eu}$ & $8.75 y$ & $\begin{array}{l}1274.8 \\
1004.8\end{array}$ & $\begin{array}{l}33.6 \simeq 0.7 \\
17.6 \pm 0.4\end{array}$ \\
\hline${ }^{155} \mathrm{Eu}$ & $4.96 \mathrm{y}$ & $\begin{array}{r}86.55 \\
105.31\end{array}$ & $\begin{array}{l}30.9 \pm 2.8 \\
20.7 \pm 2.0\end{array}$ \\
\hline
\end{tabular}

${ }^{a}$ Listed half-life is that of the parent ${ }^{106} \mathrm{Ru}$.

${ }^{b}$ The peak corresponding to detection of the $E_{y}=657.7-\mathrm{keV}$ gamma ray from decay of this isotope is masked by the very much larger peak at $661.6 \mathrm{keV}$ corresponding to decay of ${ }^{137} \mathrm{Cs}$.

e Nearly degenerate with $E_{\gamma}=428.4 \mathrm{keV}$ due to decay of ${ }^{106} \mathrm{Rh}$.

${ }^{d}$ Gamma ray due to decay of daughter ${ }^{137} \mathrm{Ba}$ isomer; branching corrected to be applicable to decay of ${ }^{137} \mathrm{Cs}$.

e Listed half-life is that of the parent ${ }^{144} \mathrm{Ce}$. 
Table 6. Absolute experimental yields (in the aliquots) of the fission product ${ }^{137} \mathrm{Cs}$ as of the end of the PFR irradiation

\begin{tabular}{|c|c|c|c|c|}
\hline \multirow{2}{*}{$\begin{array}{l}\text { Principal } \\
\text { isotope }\end{array}$} & \multirow{2}{*}{$\begin{array}{c}\text { Sample } \\
\text { No. }\end{array}$} & \multicolumn{2}{|c|}{ Yields (atoms) } & \multirow{2}{*}{$\begin{array}{c}\text { Ratio } \\
\text { FP-4:FP-2 }\end{array}$} \\
\hline & & $\mathrm{FP}-4$ & $\mathrm{FP}-2^{b}$ & \\
\hline${ }^{230} \mathrm{Th}$ & 31 & $(8.51 \pm 0.07) \times 10^{14}$ & $1.98 \times 10^{13}$ & 43.0 \\
\hline${ }^{232} \mathrm{Th}$ & 25 & $(7.96 \pm 0.44) \times 10^{14}$ & $1.11 \times 10^{13}$ & 71.8 \\
\hline${ }^{231} \mathrm{~Pa}$ & 29 & $(4.78 \pm 0.27) \times 10^{13}$ & $1.49 \times 10^{12}$ & 32.0 \\
\hline${ }^{233} \mathrm{U}$ & 32 & $(1.77 \pm 0.05) \times 10^{15}$ & $1.602 \times 10^{14}$ & 11.1 \\
\hline${ }^{234} U$ & 27 & $(5.83 \pm 0.33) \times 10^{14}$ & $3.00 \times 10^{13}$ & 19.5 \\
\hline${ }^{235} \mathrm{U}$ & 28 & $(9.21 \pm 0.26) \times 10^{14}$ & $1.64 \times 10^{14}$ & 5.6 \\
\hline${ }^{236} \mathrm{U}$ & 26 & $(6.74 \cdot 0.38) \times 10^{14}$ & $6.33 \times 10^{13}$ & 10.6 \\
\hline${ }^{238} \mathrm{U}$ & 11 & $(2.31 \pm 0.06) \times 10^{14}$ & $2.97 \times 10^{13}$ & 7.8 \\
\hline${ }^{237} \mathrm{~Np}$ & 7 & $(1.77 \pm 0.10) \times 10^{15}$ & $6.94 \times 10^{13}$ & 25.5 \\
\hline${ }^{238} \mathrm{Pu}$ & 30 & $(7.40 \pm 0.48) \times 10^{14}$ & $6.84 \times 10^{13}$ & 10.8 \\
\hline${ }^{239} \mathrm{Pu}$ & 23 & $(1.12 \pm 0.07) \times 10^{15}$ & $1.39 \times 10^{14}$ & 8.0 \\
\hline${ }^{240} \mathrm{Pu}$ & 21 & $(1.14 \pm 0.07) \times 10^{15}$ & $8.10 \times 10^{13}$ & 14.1 \\
\hline${ }^{240} \mathrm{Pu}$ & 22 & $(1.49 \pm 0.10) \times 10^{15}$ & $1.08 \times 10^{14}$ & 13.8 \\
\hline${ }^{241} \mathrm{Pu}$ & 24 & $(8.30 \pm 0.54) \times 10^{14}$ & $9.45 \times 10^{13}$ & 8.8 \\
\hline${ }^{242} \mathrm{Pu}$ & 16 & $(1.44 \pm 0.04) \times 10^{14}$ & $2.53 \times 10^{13}$ & 5.7 \\
\hline${ }^{244} \mathrm{Pu}$ & 20 & $(4.95 \pm 0.28) \times 10^{14}$ & $3.53 \times 10^{13}$ & 14.0 \\
\hline${ }^{241} \mathrm{Am}$ & 14 & $(2.61 \pm 0.29) \times 10^{14}$ & $1.80 \times 10^{13}$ & 14.5 \\
\hline${ }^{241} \mathrm{Am}$ & 15 & $(5.23 \pm 0.34) \times 10^{14}$ & $3.60 \times 10^{13}$ & 14.5 \\
\hline${ }^{243} \mathrm{Am}$ & 12 & $(1.48 \pm 0.05) \times 10^{14}$ & $1.26 \times 10^{13}$ & 11.7 \\
\hline${ }^{243} \mathrm{Am}$ & 13 & $(2.93 \pm 0.08) \times 10^{14}$ & $2.41 \times 10^{13}$ & 12.2 \\
\hline${ }^{243} \mathrm{Cm}$ & 10 & $(4.13 \pm 0.11) \times 10^{13}$ & $5.80 \times 10^{12}$ & 7.1 \\
\hline${ }^{244} \mathrm{Cm}$ & 9 & $(8.52=0.55) \times 10^{14}$ & $8.01 \times 10^{13}$ & 10.6 \\
\hline${ }^{246} \mathrm{Cm}$ & 5 & $(1.76 \pm 0.11) \times 10^{14}$ & $2.26 \times 10^{13}$ & 7.8 \\
\hline${ }^{246} \mathrm{Cm}$ & 6 & $(8.81 \pm 0.57) \times 10^{14}$ & $1.15 \times 10^{14}$ & 7.7 \\
\hline${ }^{248} \mathrm{Cm}$ & 4 & $(1.64 \pm 0.05) \times 10^{14}$ & $1.78 \times 10^{13(c)}$ & 9.2 \\
\hline
\end{tabular}

${ }^{a}$ Sept. 1, 1983 for FP-2; July 7, 1988 for FP-4.

${ }^{b}$ Renormalized from data in Table 10 of Ref. 5 to the same computed masses used in the present experiment.

c Datum from FP-1 (Ref. 4). 
Table 7. FP-4: yields of fission products deduced by gamma-ray assay

\begin{tabular}{|c|c|c|c|c|c|}
\hline \multirow{2}{*}{$\begin{array}{l}\text { Principal } \\
\text { isotope }\end{array}$} & \multirow{2}{*}{$\begin{array}{c}\text { Sample } \\
\text { No. }\end{array}$} & \multicolumn{4}{|c|}{ Fission-product yield (atoms) ${ }^{a}$} \\
\hline & & ${ }^{106} \mathrm{Ru}^{b}$ & ${ }^{125} \mathrm{Sb}$ & ${ }^{14} \mathrm{Ce}^{c}$ & ${ }^{155} \mathrm{Eu}$ \\
\hline $\begin{array}{l}{ }^{230} \mathrm{Th} \\
{ }^{232} \mathrm{Th}\end{array}$ & $\begin{array}{l}31 \\
25\end{array}$ & $(2.82 \pm 0.20) \times 10^{12}$ & $\begin{array}{l}(8.40 \pm 0.33) \times 10^{11} \\
(1.26 \pm 0.07) \times 10^{13}\end{array}$ & $\begin{array}{l}(3.33 \pm 0.06) \times 10^{13} \\
(2.88 \pm 0.09) \times 10^{14}\end{array}$ & $\begin{array}{l}(1.34 \pm 0.13) \times 10^{11} \\
(2.33 \pm 0.16) \times 10^{12}\end{array}$ \\
\hline${ }^{231} \mathrm{~Pa}$ & 29 & $(3.37 \pm 0.35) \times 10^{11}$ & $(7.23 \pm 0.40) \times 10^{11}$ & $(1.47 \pm 0.15) \times 10^{13}$ & $(1.22 \pm 0.09) \times 10^{11}$ \\
\hline $\begin{array}{l}{ }^{233} \mathrm{U} \\
{ }^{234} \mathrm{U} \\
{ }^{235} \mathrm{U} \\
{ }^{236} \mathrm{U} \\
{ }^{238} \mathrm{U}\end{array}$ & $\begin{array}{l}32 \\
27 \\
28 \\
26 \\
11\end{array}$ & $\begin{array}{l}(2.10 \pm 0.15) \times 10^{13} \\
(1.42 \pm 0.10) \times 10^{13} \\
(2.58 \pm 0.18) \times 10^{13} \\
(3.28 \pm 0.23) \times 10^{13} \\
(4.79 \pm 0.34) \times 10^{13}\end{array}$ & $\begin{array}{l}(1.89 \pm 0.08) \times 10^{13} \\
(4.94 \pm 0.25) \times 10^{12} \\
(6.52 \pm 0.22) \times 10^{12} \\
(4.26 \pm 0.29) \times 10^{12} \\
(3.62 \pm 0.13) \times 10^{12}\end{array}$ & $\begin{array}{l}(3.45 \pm 0.12) \times 10^{14} \\
(1.94 \pm 0.07) \times 10^{14} \\
(5.00 \pm 0.15) \times 10^{14} \\
(2.18 \pm 0.07) \times 10^{14} \\
(6.90 \pm 0.29) \times 10^{13}\end{array}$ & $\begin{array}{l}(5.22 \pm 0.36) \times 10^{12} \\
(2.67 \pm 0.19) \times 10^{12} \\
(9.69 \pm 0.69) \times 10^{12} \\
(5.80 \pm 0.41) \times 10^{12} \\
(5.00 \pm 0.35) \times 10^{12}\end{array}$ \\
\hline${ }^{237} \mathrm{~Np}$ & 7 & $(5.30 \pm 0.37) \times 10^{13}$ & $(2.89 \pm 0.10) \times 10^{13}$ & $(4.52 \pm 0.22) \times 10^{14}$ & $(3.24 \pm 0.33) \times 10^{13}$ \\
\hline $\begin{array}{l}{ }^{238} \mathrm{Pu} \\
{ }^{239} \mathrm{Pu} \\
{ }^{240} \mathrm{Pu} \\
{ }^{241} \mathrm{Pu} \\
{ }^{242} \mathrm{Pu} \\
{ }^{244} \mathrm{Pu}\end{array}$ & $\begin{array}{l}30 \\
23 \\
21 \\
22 \\
24 \\
16 \\
20\end{array}$ & $\begin{array}{l}(1.28 \pm 0.09) \times 10^{14} \\
(3.34 \pm 0.24) \times 10^{13} \\
(2.71 \pm 0.19) \times 10^{13} \\
(5.47 \pm 0.38) \times 10^{13} \\
(9.62 \pm 0.68) \times 10^{13} \\
(1.61 \pm 0.11) \times 10^{13} \\
(5.05 \pm 0.35) \times 10^{13}\end{array}$ & $\begin{array}{l}(1.91 \pm 0.10) \times 10^{13} \\
(1.04 \pm 0.08) \times 10^{13} \\
(1.09 \pm 0.07) \times 10^{13} \\
(1.40 \pm 0.09) \times 10^{13} \\
(6.86 \pm 0.42) \times 10^{12} \\
(1.12 \pm 0.04) \times 10^{12} \\
(3.59 \pm 0.20) \times 10^{12}\end{array}$ & $\begin{array}{l}(1.43 \pm 0.10) \times 10^{14} \\
(1.54 \pm 0.05) \times 10^{14} \\
(3.05 \pm 0.10) \times 10^{14} \\
(3.63 \pm 0.11) \times 10^{14} \\
(1.79 \pm 0.06) \times 10^{14} \\
(4.37 \pm 0.13) \times 10^{13} \\
(1.45 \pm 0.05) \times 10^{14}\end{array}$ & $\begin{array}{l}(1.16 \pm 0.09) \times 10^{13} \\
(2.09 \pm 0.14) \times 10^{13} \\
(3.55 \pm 0.25) \times 10^{13} \\
(4.27 \pm 0.29) \times 10^{13} \\
(2.87 \pm 0.20) \times 10^{13} \\
(5.24 \pm 0.37) \times 10^{12} \\
(2.78 \pm 0.20) \times 10^{13}\end{array}$ \\
\hline $\begin{array}{l}{ }^{241} \mathrm{Am} \\
{ }^{241} \mathrm{Am} \\
{ }^{243} \mathrm{Am} \\
{ }^{243} \mathrm{Am}\end{array}$ & $\begin{array}{l}14 \\
15 \\
12 \\
13\end{array}$ & $\begin{array}{l}(2.90 \pm 0.20) \times 10^{13} \\
(1.14 \pm 0.08) \times 10^{14} \\
(2.06 \pm 0.14) \times 10^{13} \\
(4.12 \pm 0.29) \times 10^{13}\end{array}$ & $\begin{array}{l}(6.47 \pm 0.22) \times 10^{12} \\
(1.35 \pm 0.08) \times 10^{13} \\
(2.83 \pm 0.10) \times 10^{12} \\
(5.63 \pm 0.40) \times 10^{12}\end{array}$ & $\begin{array}{l}(6.46 \pm 0.19) \times 10^{13} \\
(1.35 \pm 0.04) \times 10^{14} \\
(4.04 \pm 0.12) \times 10^{13} \\
(8.12 \pm 0.25) \times 10^{13}\end{array}$ & $\begin{array}{l}(1.04 \pm 0.07) \times 10^{13} \\
(2.11 \pm 0.15) \times 10^{13} \\
(2.57 \pm 0.18) \times 10^{13} \\
(6.13 \pm 0.43) \times 10^{13}\end{array}$ \\
\hline $\begin{array}{l}{ }^{243} \mathrm{Cm} \\
{ }^{244} \mathrm{Cm} \\
{ }^{246} \mathrm{Cm} \\
{ }^{246} \mathrm{Cm} \\
{ }^{248} \mathrm{Cm}\end{array}$ & $\begin{array}{r}10 \\
9 \\
5 \\
6 \\
4\end{array}$ & $\begin{array}{l}(5.22 \pm 0.36) \times 10^{12} \\
(3.43 \pm 0.24) \times 10^{14} \\
(7.94 \pm 0.56) \times 10^{13} \\
(2.16 \pm 0.15) \times 10^{14} \\
(5.86 \pm 0.41) \times 10^{13}\end{array}$ & $\begin{array}{l}(8.50 \pm 0.29) \times 10^{11} \\
(1.33 \pm 0.08) \times 10^{13} \\
(2.35 \pm 0.08) \times 10^{12} \\
(1.18 \pm 0.09) \times 10^{13} \\
(2.06 \pm 0.07) \times 10^{12}\end{array}$ & $\begin{array}{l}(8.50 \pm 0.26) \times 10^{12} \\
(2.27 \pm 0.08) \times 10^{14} \\
(5.30 \pm 0.20) \times 10^{13} \\
(2.70 \pm 0.16) \times 10^{14} \\
(5.57 \pm 0.17) \times 10^{13}\end{array}$ & $\begin{array}{l}(1.44 \pm 0.10) \times 10^{12} \\
(5.53 \pm 0.39) \times 10^{13} \\
(1.42 \pm 0.10) \times 10^{13} \\
(7.30 \pm 0.51) \times 10^{13} \\
(1.56 \pm 0.11) \times 10^{13}\end{array}$ \\
\hline
\end{tabular}

${ }^{a}$ As of July 7, 1988.

${ }^{b}$ From assay of ${ }^{106} \mathrm{Rh}$.

${ }^{c}$ Includes assay of ${ }^{144} \mathrm{Pr}$. 
Table 8. FP-4: yields of shielded radionuclides deduced by gamma-ray assay

\begin{tabular}{|c|c|c|c|c|c|}
\hline \multirow{2}{*}{$\begin{array}{l}\text { Principal } \\
\text { isotope }\end{array}$} & \multirow{2}{*}{$\begin{array}{l}\text { Sample } \\
\text { No. }\end{array}$} & \multicolumn{4}{|c|}{ Radionuclide yield (in atoms) $^{a}$} \\
\hline & & ${ }^{110 m} \mathrm{Ag}$ & ${ }^{134} \mathrm{Cs}$ & ${ }^{152} \mathrm{Eu}$ & ${ }^{154} \mathrm{Eu}$ \\
\hline${ }^{230} \mathrm{Th}$ & $\begin{array}{l}31 \\
25\end{array}$ & & $\begin{array}{l}(2.38 \pm 0.04) \times 10^{12} \\
(2.34 \pm 0.06) \times 10^{13}\end{array}$ & & $(1.63 \pm 0.15) \times 10^{12}$ \\
\hline${ }^{231} \mathrm{~Pa}$ & 29 & & $(1.34 \pm 0.05) \times 10^{12}$ & & $(9.15 \pm 0.50) \times 10^{10}$ \\
\hline $\begin{array}{l}{ }^{233} \mathrm{U} \\
{ }^{224} \mathrm{U} \\
{ }^{235} \mathrm{U} \\
{ }^{236} \mathrm{U}\end{array}$ & $\begin{array}{l}32 \\
27 \\
28 \\
26 \\
11\end{array}$ & $(5.64 \pm 0.96) \times 10^{10}$ & $\begin{array}{l}(7.52 \pm 0.20) \times 10^{13} \\
(2.43 \pm 0.07) \times 10^{13} \\
(4.00 \pm 0.10) \times 10^{13} \\
(3.25 \pm 0.09) \times 10^{13} \\
(8.82 \pm 0.30) \times 10^{12}\end{array}$ & & $\begin{array}{l}(5.29 \pm 0.20) \times 10^{12} \\
(2.32 \pm 0.06) \times 10^{12} \\
(9.54 \pm 0.33) \times 10^{12} \\
(4.35 \pm 0.15) \times 10^{12} \\
(2.18 \pm 0.06) \times 10^{12}\end{array}$ \\
\hline${ }^{237} \mathrm{~Np}$ & 7 & $(2.68 \pm 0.17) \times 10^{11}$ & $(6.98 \pm 0.36) \times 10^{13}$ & & $(1.43 \pm 0.08) \times 10^{13}$ \\
\hline $\begin{array}{l}{ }^{238} \mathrm{Pu} \\
{ }^{239} \mathrm{Pu} \\
{ }^{240} \mathrm{Pu} \\
{ }^{240} \mathrm{Pu} \\
{ }^{241} \mathrm{Pu} \\
{ }^{242} \mathrm{Pu} \\
{ }^{44} \mathrm{Pu}\end{array}$ & $\begin{array}{l}30 \\
23 \\
21 \\
22 \\
24 \\
16 \\
20\end{array}$ & $\begin{array}{l}(2.27 \pm 0.13) \times 10^{11} \\
(4.50 \pm 0.21) \times 10^{11} \\
(7.46 \pm 0.34) \times 10^{11} \\
(9.51 \pm 0.46) \times 10^{11} \\
(7.41 \pm 0.32) \times 10^{11} \\
(1.50 \pm 0.05) \times 10^{11} \\
(7.74 \pm 0.34) \times 10^{11}\end{array}$ & $\begin{array}{l}(3.59 \pm 0.16) \times 10^{13} \\
(5.79 \pm 0.26) \times 10^{13} \\
(4.86 \pm 0.28) \times 10^{13} \\
(6.44 \pm 0.36) \times 10^{13} \\
(4.04 \pm 0.22) \times 10^{13} \\
(6.10 \pm 0.25) \times 10^{12} \\
(1.87 \pm 0.10) \times 10^{13}\end{array}$ & $\begin{array}{l}(2.67 \pm 0.17) \times 10^{11} \\
(1.82 \pm 0.28) \times 10^{11} \\
(2.43 \pm 0.19) \times 10^{11} \\
(1.99 \pm 0.23) \times 10^{11} \\
(2.88 \pm 0.17) \times 10^{11} \\
(1.32 \pm 0.10) \times 10^{11}\end{array}$ & $\begin{array}{l}(6.40 \pm 0.25) \times 10^{12} \\
(1.19 \pm 0.06) \times 10^{13} \\
(1.58 \pm 0.06) \times 10^{13} \\
(1.90 \pm 0.10) \times 10^{13} \\
(1.51 \pm 0.09) \times 10^{13} \\
(3.04 \pm 0.09) \times 10^{12} \\
(1.08 \pm 0.04) \times 10^{13}\end{array}$ \\
\hline $\begin{array}{l}{ }^{241} \mathrm{Am} \\
{ }^{241} \mathrm{Am} \\
{ }^{243} \mathrm{Am} \\
{ }^{243} \mathrm{Am}\end{array}$ & $\begin{array}{l}14 \\
15 \\
12 \\
13\end{array}$ & $\begin{array}{l}(1.47 \pm 0.09) \times 10^{11} \\
(3.90 \pm 0.17) \times 10^{11} \\
(1.56 \pm 0.07) \times 10^{11} \\
(4.01 \pm 0.17) \times 10^{11}\end{array}$ & $\begin{array}{l}(9.81 \pm 0.62) \times 10^{12} \\
(2.02 \pm 0.07) \times 10^{13} \\
(5.20 \pm 0.21) \times 10^{12} \\
(1.04 \pm 0.06) \times 10^{13}\end{array}$ & $\begin{array}{l}(8.24 \pm 0.40) \times 10^{10} \\
(1.61 \pm 0.24) \times 10^{11} \\
(7.35 \pm 0.60) \times 10^{10}\end{array}$ & $\begin{array}{l}(4.55 \pm 0.12) \times 10^{12} \\
(9.21 \pm 0.35) \times 10^{12} \\
(3.39 \pm 0.16) \times 10^{12} \\
(6.75 \pm 0.31) \times 10^{12}\end{array}$ \\
\hline $\begin{array}{l}{ }^{243} \mathrm{Cm} \\
{ }^{244} \mathrm{Cm} \\
{ }^{246} \mathrm{Cm} \\
{ }^{246} \mathrm{Cm} \\
{ }^{248} \mathrm{Cm}\end{array}$ & $\begin{array}{r}10 \\
9 \\
5 \\
6 \\
4\end{array}$ & $\begin{array}{l}(6.34 \pm 0.33) \times 10^{10} \\
(1.18 \pm 0.07) \times 10^{12} \\
(3.10 \pm 0.15) \times 10^{11} \\
(7.32 \pm 0.43) \times 10^{11} \\
(3.40 \pm 0.14) \times 10^{11}\end{array}$ & $\begin{array}{l}(1.74 \pm 0.07) \times 10^{12} \\
(3.00 \pm 0.18) \times 10^{13} \\
(5.83 \pm 0.34) \times 10^{12} \\
(2.96 \pm 0.13) \times 10^{13} \\
(5.54 \pm 0.23) \times 10^{12}\end{array}$ & $\begin{array}{l}(3.46 \pm 0.30) \times 10^{10} \\
(3.07 \pm 0.20) \times 10^{11} \\
(6.72 \pm 0.50) \times 10^{10} \\
(2.53 \pm 0.16) \times 10^{11}\end{array}$ & $\begin{array}{l}(1.28 \pm 0.04) \times 10^{12} \\
(1.89 \pm 0.09) \times 10^{13} \\
(4.72 \pm 0.22) \times 10^{12} \\
(2.40 \pm 0.11) \times 10^{13}\end{array}$ \\
\hline
\end{tabular}

a As of July 7, 1988. 
Table 9. FP-4: comparison of post-irradiation actinide sample masses measured by two methods. The listed values are for the aliquots.

\begin{tabular}{lcccc}
\hline $\begin{array}{l}\text { Principal } \\
\text { isotope }\end{array}$ & $\begin{array}{c}\text { Sample } \\
\text { No. }\end{array}$ & $\begin{array}{c}\text { Aliquot } \\
(\%)\end{array}$ & \multicolumn{2}{c}{ Mass $(\mu \mathrm{g})$} \\
\cline { 4 - 5 } & & & $\begin{array}{c}\text { Gamma-ray } \\
\text { assay }\end{array}$ & Radiometric \\
\hline${ }^{238} \mathrm{Pu}$ & 30 & 2.0 & $11.7 \pm 0.5$ & $13 \pm 1$ \\
${ }^{241} \mathrm{Pu}$ & 24 & 0.4 & $7.5 \pm 0.5$ & $7.8 \pm 0.4$ \\
${ }^{241} \mathrm{Am}$ & 14 & 0.2 & $11.1 \pm 0.5$ & $12.4 \pm 0.6$ \\
${ }^{241} \mathrm{Am}$ & 15 & 0.4 & $21.7 \pm 1.1$ & $25.4 \pm 1.3$ \\
${ }^{243} \mathrm{Am}$ & 12 & 0.2 & $11.7 \pm 0.4$ & $13.6 \pm 0.7$ \\
${ }^{243} \mathrm{Am}$ & 13 & 0.4 & $23.2 \pm 0.8$ & $26.4 \pm 1.3$ \\
${ }^{243} \mathrm{Cm}$ & 10 & 0.1 & $0.190 \pm 0.010$ & $0.22 \pm 0.01$ \\
\hline
\end{tabular}

${ }^{a}$ From Table 4.

${ }^{b}$ At the end of irradiation (July 7,1988 ).

${ }^{c}$ From tabular value in Appendix B, row B "After irradiation," final column multiplied by the $\gamma$-ray aliquot at date given in the next row.

Uncertainty assumed to be $5 \%$.

Table 10. FP-4: actinides produced in neutron capture by principal isotopes deduced by gamma-ray assay. The listed values are for the aliquots.

\begin{tabular}{|c|c|c|c|c|}
\hline $\begin{array}{l}\text { Principal } \\
\text { isotope }\end{array}$ & $\begin{array}{c}\text { Sample } \\
\text { No. }\end{array}$ & $\begin{array}{l}\text { Aliquot }^{\sigma} \\
(\%)\end{array}$ & $\begin{array}{l}\text { Capture } \\
\text { product }\end{array}$ & Yield $^{b, c}$ (atoms) \\
\hline${ }^{231} \mathrm{~Pa}$ & 29 & 0.1 & ${ }^{232} \mathrm{U}$ & $1.50 \times 10^{15}$ \\
\hline $\begin{array}{l}{ }^{240} \mathrm{Pu} \\
{ }^{240} \mathrm{Pu} \\
{ }^{242} \mathrm{Pu} \\
{ }^{244} \mathrm{Pu}\end{array}$ & $\begin{array}{l}21 \\
22 \\
16 \\
20\end{array}$ & $\begin{array}{l}0.6 \\
0.8 \\
2.0 \\
2.0\end{array}$ & $\begin{array}{l}{ }^{241} \mathrm{Am} \\
{ }^{241} \mathrm{Am} \\
{ }^{243} \mathrm{Am} \\
{ }^{245} \mathrm{Cm}\end{array}$ & $\begin{array}{l}2.24 \times 10^{15} \text { at EOI }+651 \mathrm{~d} \\
2.71 \times 10^{15} \text { at } \mathrm{EOI}+664 \mathrm{~d} \\
2.81 \times 10^{15} \\
4.33 \times 10^{15}\end{array}$ \\
\hline $\begin{array}{l}{ }^{241} \mathrm{Am} \\
{ }^{241} \mathrm{Am}\end{array}$ & $\begin{array}{l}14 \\
15\end{array}$ & $\begin{array}{l}0.2 \\
0.4\end{array}$ & $\begin{array}{l}{ }^{2420} \mathrm{Am}^{d} \\
{ }^{242 m} \mathrm{Am}^{d}\end{array}$ & $\begin{array}{l}4.70 \times 10^{15} \\
1.00 \times 10^{16}\end{array}$ \\
\hline $\begin{array}{l}{ }^{244} \mathrm{Cm} \\
{ }^{248} \mathrm{Cm}\end{array}$ & $\begin{array}{l}9 \\
4\end{array}$ & $\begin{array}{l}0.6 \\
1.0\end{array}$ & $\begin{array}{l}{ }^{245} \mathrm{Cm} \\
{ }^{249} \mathrm{Cf}\end{array}$ & $\begin{array}{l}8.07 \times 10^{15} \\
1.70 \times 10^{15}\end{array}$ \\
\hline
\end{tabular}

${ }^{a}$ From Table 4.

${ }^{b}$ At end of irradiation (July 7,1988 ), except as noted.

c Uncertainty is $\pm 5 \%$.

${ }^{d}$ From assay of $16-\mathrm{h}{ }^{242} \mathrm{Am}$ daughter. 
Table 11. FP-4: yields of actinides other than principal and capture nuclides as deduced by gamma-ray assay

\begin{tabular}{|c|c|c|c|c|}
\hline $\begin{array}{l}\text { Principal } \\
\text { isotope }\end{array}$ & $\begin{array}{c}\text { Sample } \\
\text { No. }\end{array}$ & $\begin{array}{c}\text { Measured } \\
\text { actinide }\end{array}$ & $\begin{array}{c}\text { Yield } \\
\text { (atoms) }\end{array}$ & $\begin{array}{l}\text { Cooling time } \\
\text { (days) }\end{array}$ \\
\hline${ }^{230} \mathrm{Th}$ & 31 & ${ }^{209} \mathrm{Th}$ & $(7.41 \pm 0.37) \times 10^{13}$ & 609 \\
\hline${ }^{230} \mathrm{Th}$ & 31 & ${ }^{232} \mathrm{U}$ & $(1.42 \pm 0.04) \times 10^{15}$ & 609 \\
\hline${ }^{232} \mathrm{Th}$ & 25 & ${ }^{228} \mathrm{Th}$ & $(1.22 \pm 0.07) \times 10^{12}$ & 621 \\
\hline${ }^{231} \mathrm{~Pa}$ & 29 & ${ }^{228} \mathrm{Th}$ & $(1.06 \pm 0.06) \times 10^{14}$ & 632 \\
\hline${ }^{233} \mathrm{U}$ & 32 & ${ }^{20} \mathrm{Th}$ & $(1.15 \pm 0.07) \times 10^{11}$ & 618 \\
\hline${ }^{234} \mathrm{U}$ & 27 & ${ }^{208} \mathrm{Th}$ & $(1.20 \pm 0.07) \times 10^{11}$ & 629 \\
\hline${ }^{237} \mathrm{~Np}$ & 7 & ${ }^{209} \mathrm{Th}$ & $(9.4 \pm 2.0) \times 10^{10}$ & 609 \\
\hline${ }^{239} \mathrm{Pu}$ & 23 & ${ }^{241} \mathrm{Am}$ & $(2.93 \pm 0.29) \times 10^{13}$ & 659 \\
\hline${ }^{241} \mathrm{Pu}$ & 24 & ${ }^{241} \mathrm{Am}$ & $(1.51 \pm 0.05) \times 10^{16}$ & 666 \\
\hline${ }^{242} \mathrm{Pu}$ & 16 & ${ }^{241} \mathrm{Am}$ & $(2.71 \pm 0.24) \times 10^{13}$ & 679 \\
\hline${ }^{24} \mathrm{Pu}$ & 20 & ${ }^{241} \mathrm{Am}$ & $(3.56 \pm 0.18) \times 10^{14}$ & 677 \\
\hline${ }^{24} \mathrm{Pu}$ & 20 & ${ }^{243} \mathrm{Am}$ & $(8.88 \pm 0.36) \times 10^{14}$ & 1355 \\
\hline${ }^{241} \mathrm{Am}$ & 14 & ${ }^{243} \mathrm{Am}$ & $(1.89 \pm 0.09) \times 10^{14}$ & 1351 \\
\hline${ }^{241} \mathrm{Am}$ & 14 & ${ }^{243} \mathrm{Cm}$ & $(2.45 \pm 0.08) \times 10^{14}$ & 1351 \\
\hline${ }^{243} \mathrm{Cm}$ & 10 & ${ }^{241} \mathrm{Am}$ & $(4.10 \pm 0.20) \times 10^{13}$ & 650 \\
\hline${ }^{244} \mathrm{Cm}$ & 9 & ${ }^{241} \mathrm{Am}$ & $(3.57 \pm 0.16) \times 10^{14}$ & 638 \\
\hline${ }^{246} \mathrm{Cm}$ & 5 & ${ }^{211} \mathrm{Am}$ & $(2.44 \pm 0.24) \times 10^{13}$ & 649 \\
\hline${ }^{246} \mathrm{Cm}$ & 5 & ${ }^{2 A 5} \mathrm{Cm}$ & $(1.86 \pm 0.36) \times 10^{15}$ & 649 \\
\hline${ }^{246} \mathrm{Cm}$ & 5 & ${ }^{249} \mathrm{Cf}$ & $(2.06 \pm 0.12) \times 10^{14}$ & 649 \\
\hline${ }^{246} \mathrm{Cm}$ & 6 & ${ }^{2 A 5} \mathrm{Cm}$ & $(3.6 \pm 1.3) \times 10^{14}$ & 665 \\
\hline${ }^{246} \mathrm{Cm}$ & 6 & ${ }^{249} \mathrm{Cf}$ & $(9.60 \pm 0.39) \times 10^{14}$ & 665 \\
\hline${ }^{248} \mathrm{Cm}$ & 4 & ${ }^{241} \mathrm{Am}$ & $(7.8 \pm 1.2) \times 10^{12}$ & 684 \\
\hline
\end{tabular}

${ }^{a}$ After end of irradiation. 
Table 12 FP-4: dosimeter yields deduced by gamma-ray assay

\begin{tabular}{|c|c|c|c|c|c|}
\hline \multirow[t]{2}{*}{ Dosimeter } & \multirow[t]{2}{*}{ Position } & \multirow{2}{*}{$\begin{array}{l}\text { Mass } \\
(\mathrm{mg})\end{array}$} & \multirow{2}{*}{$\begin{array}{l}\text { Gamma-ray } \\
\text { aliquot (\%) }\end{array}$} & \multicolumn{2}{|c|}{ Yield (atoms) ${ }^{a}$} \\
\hline & & & & ${ }^{137} \mathrm{Cs}$ & ${ }^{60} \mathrm{Co}$ \\
\hline${ }^{235} \mathrm{U}$ & $\begin{array}{l}1 \mathrm{~A} \\
1 \mathrm{~B}\end{array}$ & $\left.\begin{array}{l}1.174 \\
1.180\end{array}\right\}$ & 1.0 & $(5.54 \pm 0.17) \times 10^{14}$ & \\
\hline${ }^{239} \mathrm{Pu}$ & $\begin{array}{l}2 \mathrm{~A} \\
2 \mathrm{~B}\end{array}$ & $\left.\begin{array}{l}1.196 \\
1.044\end{array}\right\}$ & 12.0 & $(7.76 \pm 0.29) \times 10^{15}$ & \\
\hline $\begin{array}{l}\mathrm{Co} \\
\mathrm{Cu}\end{array}$ & $\begin{array}{l}3 \mathrm{~A} \\
3 \mathrm{~B}\end{array}$ & $\begin{array}{l}0.00150 \\
1.353\end{array}$ & $\begin{array}{l}2.0 \\
2.0\end{array}$ & & $\begin{array}{l}(4.45 \pm 0.11) \times 10^{12} \\
(9.90 \pm 0.24) \times 10^{11}\end{array}$ \\
\hline${ }^{235} \mathrm{U}$ & $\begin{array}{l}17 \mathrm{~A} \\
17 \mathrm{~B}\end{array}$ & $\left.\begin{array}{l}1.106 \\
0.982\end{array}\right\}$ & 0.4 & $(2.22 \pm 0.07) \times 10^{14}$ & \\
\hline $\begin{array}{l}{ }^{239} \mathrm{Pu} \\
{ }^{237} \mathrm{~Np}\end{array}$ & $\begin{array}{l}18 \mathrm{~A} \\
18 \mathrm{~B}\end{array}$ & $\left.\begin{array}{l}1.140 \\
1.124\end{array}\right\}$ & 12.0 & $(8.16 \pm 0.34) \times 10^{15}$ & \\
\hline $\begin{array}{l}\mathrm{Co} \\
\mathrm{Cu}\end{array}$ & $\begin{array}{l}19 \mathrm{~A} \\
19 \mathrm{~B}\end{array}$ & $\begin{array}{l}0.00157 \\
1.406\end{array}$ & $\begin{array}{l}2.0 \\
2.0\end{array}$ & & $\begin{array}{l}(5.61 \pm 0.14) \times 10^{12} \\
(1.63 \pm 0.04) \times 10^{12}\end{array}$ \\
\hline${ }^{239} \mathrm{Pu}$ & $\begin{array}{l}34 \mathrm{~A} \\
34 \mathrm{~B}\end{array}$ & $\left.\begin{array}{l}1.184 \\
1.184\end{array}\right\}$ & 12.0 & $(1.14 \pm 0.05) \times 10^{16}$ & \\
\hline $\begin{array}{l}\mathrm{Co} \\
\mathrm{Cu}\end{array}$ & $\begin{array}{l}35 \mathrm{~A} \\
35 \mathrm{~B}\end{array}$ & $\begin{array}{l}0.00143 \\
1.433\end{array}$ & $\begin{array}{l}2.0 \\
2.0\end{array}$ & & $\begin{array}{l}(4.91 \pm 0.12) \times 10^{12} \\
(1.01 \pm 0.03) \times 10^{12}\end{array}$ \\
\hline
\end{tabular}

${ }^{a}$ As of July 7, 1988. 


\section{CONCLUSIONS}

Summarized are the analytical methodologies used to measure the isotopic compositions and concentrations of actinides and their reaction products for FP-1, FP-2, and FP-4 irradiated in the Dounreay prototype fast reactor. These measurements have been made using the best laboratory practices possible under the difficult constraints of the use of highly radioactive materials and the small quantities usually selected or produced in bombardment or fission. Some data from FP-1 and FP-2 are suspect. However, the lessons learned from these were of great value in improving the analytical techniques for the more crucial FP-4.

Similarly, experience gained from the study of gamma-ray assay of the samples from FP-1 and FP-2 was invaluable for measurements involving the samples of FP-4. The much more extensive burnup of FP-4 enhanced the production of "second-order" radionuclides as exemplified by observed yields of shielded fission products as well as the wide variations in observed yields of the radionuclide ${ }^{137} \mathrm{Cs}$ resulting from different fissioning rates between the principal actinide in a sample and "grown-in" actinides.

These data should provide a substantial basis for future analytical analyses of fuel-rod radionuclide composition during and following use of the material in a fast reactor. 


\section{REFERENCES}

1. T. C. Quinby, H. L. Adair, E. H. Kobisk, D. W. Ramey, J. A. Setaro, J. L. Botts, J. H. Cooper, R. L. Walker, J. E. Bigelow, J. R. Gibson, W. T. Martin, R. G. Pope, and S. Raman, Preparation of Actinide Specimens for the US/UK Joint Experiment in the Dounreay Prototype Fast Reactor, ORNL-5858, May 1982.

2. R. L. Walker, J. L. Botts, J. H. Cooper, H. L. Adair, J. E. Bigelow, and S. Raman, Characterization of Actinide Physics Specimens for the US/UK Joint Experiment in the Dounreay Prototype Fast Reactor, ORNL-5986, October 1983.

3. B. L. Broadhead, N. B. Gove, and S. Raman, Preanalysis Calculations of the US/UK Joint Experiment in the Dounreay Prototype Fast Reactor, ORNL-6058, May 1984.

4. J. K. Dickens and S. Raman, Fission-Product Yield Data from the US/UK Joint Experiment in the Dounreay Prototype Fast Reactor, ORNL-6266, April 1986.

5. S. Raman, B. L. Broadhead, J. K. Dickens, R. L. Walker, and J. L. Botts, Analyses of Physics Specimens in Fuel Pins 1 and 2 Irradiated in the Dounreay Prototype Fast Reactor, ORNL-6632, January 1992.

6. F. A. White and T. L. Collins, Appl. Spectros. 8, 17 (1954).

7. D. H. Smith, Chem., Biomed. and Environ. Instrum. 10, 27 (1980).

8. R. L. Walker, R. E. Eby, C. A. Pritchard, and J. A. Carter, Anal. Lett. 7, 563 (1974).

9. R. L. Walker, C. A. Pritchard, J. A. Carter. and D. H. Smith, Practical Aspects of the Resin Bead Technique for Mass Spectrometric Sample Handling, ORNL/TM-5505, 1976.

10. E. Storm and H. I. Israel, Nucl. Data Tables A7, 565 (1970).

11. J. K. Dickens, TPASS, A Gamma-Ray Spectrum Analysis and Isotope Identification Computer Code, ORNL-5732, March 1981.

12. C. M. Lederer, V. S. Shirley, E. Browne, J. M. Dairiki, R. E. Doebler, A. A. ShihabEldin, L. J. Jardine, J. K. Tuli, and A. B. Buyrn, Table of Isotopes, Seventh Edition, John Wiley and Sons, Inc., New York, 1978.

13. TPASGAM, Radioactive Decay Library of Gamma-Ray Energies, Branching Ratios, and Cross Sections, RSIC Data Library Collection Report No. DLC-88 (1982) of the Oak Ridge National Laboratory. 
APPENDIX A

METHODS USED TO ANALYZE ACTINIDE MATERIAIS 


\section{APPENDIX A}

\section{METHODS USED TO ANALYZE ACTINIDE MATERIALS}

The symbols MS and RCA denote mass spectrometry (isotope dilution) and radiochemical analysis (alpha and gamma spectro-scopy), respectively.

\begin{tabular}{|c|c|c|c|c|}
\hline \multirow[b]{2}{*}{ Position in FP } & \multirow[b]{2}{*}{ Material } & \multicolumn{3}{|c|}{ Method Used } \\
\hline & & Isotopic by MS & $\begin{array}{c}\text { Concentration } \\
\text { by MS }\end{array}$ & $\begin{array}{c}\text { Concentration } \\
\text { by RCA }\end{array}$ \\
\hline 1 & $\begin{array}{l}\text { Dos }(U-235) \\
\text { Dos (U-238) }\end{array}$ & $\begin{array}{l}x \\
x\end{array}$ & $\begin{array}{l}x \\
x\end{array}$ & \\
\hline 2 & $\begin{array}{l}\text { Dos }(\mathrm{Pu}-239) \\
\text { Dos }(\mathrm{Np}-237)\end{array}$ & $\mathbf{x}$ & $x$ & $\mathbf{x}$ \\
\hline 3 & $\begin{array}{l}\text { Dos }(\mathrm{Cu}) \\
\operatorname{Dos}(\mathrm{Co})\end{array}$ & & & $\begin{array}{l}\mathbf{x} \\
\mathbf{x}\end{array}$ \\
\hline 4 & $\mathrm{Cm}-248$ & $\mathrm{x}$ & & $\mathbf{x}$ \\
\hline 5 & $\mathrm{Cm}-246$ & $x$ & & $\mathbf{x}$ \\
\hline 6 & $\mathrm{Cm}-246$ & $\mathbf{x}$ & & $\mathbf{x}$ \\
\hline 7 & $\mathrm{~Np}-237$ & $\mathbf{x}$ & & $\mathbf{x}$ \\
\hline 8 & $\mathrm{Cm}-244$ & $\mathrm{x}$ & & $\mathbf{x}$ \\
\hline 9 & $\mathrm{Cm}-244$ & $\mathbf{x}$ & & $\mathbf{x}$ \\
\hline 10 & $\mathrm{Cm}-243$ & $\mathbf{x}$ & & $\mathbf{x}$ \\
\hline 11 & U-238 & $\mathbf{x}$ & $\mathbf{x}$ & \\
\hline 12 & Am-243 & $\mathbf{x}$ & & $\mathbf{x}$ \\
\hline 13 & Am-243 & $\mathbf{x}$ & & $\mathbf{x}$ \\
\hline 14 & Am-241 & $\mathbf{x}$ & & $\mathbf{x}$ \\
\hline 15 & Am-241 & $\mathbf{x}$ & & $\mathbf{x}$ \\
\hline 16 & $\mathrm{Pu}-242$ & $\mathbf{x}$ & $\mathbf{x}$ & \\
\hline 17 & $\begin{array}{l}\text { Dos (U-235) } \\
\text { Dos (U-238) }\end{array}$ & $\begin{array}{l}\mathbf{x} \\
\mathbf{x}\end{array}$ & $\begin{array}{l}\mathbf{x} \\
\mathbf{x}\end{array}$ & \\
\hline 18 & $\begin{array}{l}\text { Dos }(\mathrm{Pu}-239) \\
\text { Dos }(\mathrm{Np}-237)\end{array}$ & $\mathbf{x}$ & $\mathbf{x}$ & $\mathbf{x}$ \\
\hline 19 & $\begin{array}{l}\text { Dos }(\mathrm{Cu}) \\
\text { Dos }(\mathrm{Co})\end{array}$ & & . & $\begin{array}{l}x \\
x\end{array}$ \\
\hline
\end{tabular}


Appendix A (continued)

\begin{tabular}{|c|c|c|c|c|}
\hline \multirow[b]{2}{*}{ Position in FP } & \multirow[b]{2}{*}{ Material } & \multicolumn{3}{|c|}{ Method Used } \\
\hline & & Isotopic by MS & $\begin{array}{c}\text { Concentration } \\
\text { by MS }\end{array}$ & $\begin{array}{l}\text { Concentration } \\
\text { by RCA }\end{array}$ \\
\hline & . & & & \\
\hline 20 & $\mathrm{Pu}-244$ & $\mathbf{x}$ & $\mathbf{x}$ & \\
\hline 21 & $\mathrm{Pu}-240$ & $\mathbf{x}$ & $\mathbf{x}$ & \\
\hline 22 & $\mathrm{Pu}-240$ & $\mathbf{x}$ & $\mathbf{x}$ & \\
\hline 23 & $\mathrm{Pu}-239$ & $x$ & $\mathbf{x}$ & \\
\hline 24 & $\mathrm{Pu}-241$ & $\mathbf{x}$ & $\mathbf{x}$ & \\
\hline 25 & Th-232 & $\mathbf{x}$ & $\mathbf{x}$ & \\
\hline 26 & U-236 & $\mathbf{x}$ & $\mathbf{x}$ & \\
\hline 27 & U-234 & $\mathbf{x}$ & $\mathbf{x}$ & \\
\hline 28 & U-235 & $\mathbf{x}$ & $\mathbf{x}$ & \\
\hline 29 & $\mathrm{~Pa}-231$ & & & $\mathbf{x}$ \\
\hline 30 & $\mathrm{Pu}-238$ & $x$ & & $x$ \\
\hline 31 & Th-230 & $\mathbf{x}$ & $\mathbf{x}$ & \\
\hline 32 & $\mathrm{U}-233$ & $\mathbf{x}$ & $\mathbf{x}$ & \\
\hline 33 & $\begin{array}{l}\text { Dos (U-235) } \\
\text { Dos (U-238) }\end{array}$ & $\begin{array}{l}\mathbf{x} \\
\mathbf{x}\end{array}$ & $\begin{array}{l}\mathbf{x} \\
\mathbf{x}\end{array}$ & \\
\hline 34 & $\begin{array}{l}\text { Dos (Pu-239) } \\
\text { Dos (Np-237) }\end{array}$ & $\mathbf{x}$ & $\mathbf{x}$ & $\mathrm{x}$ \\
\hline 35 & $\begin{array}{l}\text { Dos (Co) } \\
\text { Dos (Co) }\end{array}$ & & & $\begin{array}{l}\mathbf{x} \\
\mathbf{x}\end{array}$ \\
\hline
\end{tabular}

A-3 
Appendix B

ANALYTICAL DATA FOR IRRADIATED ACTINIDE PHYSICS SPECIMENS

(See also Ref. 5 for FP-1 and FP-2 Data) 
Sample data for ${ }^{218} \mathrm{Cm}$, Capsule Position 4

A. Isotopic Composition, at. \%

$\begin{array}{lc} & \begin{array}{c}\text { At start } \\ \text { Date: }\end{array} \\ & \text { Feb. 11, 1981 } \\ 244 & 3.231 \\ 245 & 0.102 \\ 246 & 4.516 \\ 247 & 0.086 \\ 248 & 92.065\end{array}$

$\begin{array}{cccc}\begin{array}{c}\text { FP-1 } \\ \text { Aug. 13, 1984 }\end{array} & \begin{array}{c}\text { FP-2* } \\ \text { Oct. 16, 1986 }\end{array} & \begin{array}{c}\text { FP-4 } \\ \text { Oct. 17, 1990 }\end{array} \\ 2.84 & & & 2.08 \\ 0.149 & 0.58 & 0.36 \\ 4.54 & 4.51 & & 4.50 \\ 0.137 & 0.136 & & 0.41 \\ 92.33 & 92.62 & 92.65\end{array}$

B. Concentration, $\mathrm{mg}^{248} \mathrm{Cm}$

At start

After irradiation

1.70

1.61

July 24, 1984

1.76

1.76

Date of measurement

C. Additional Postirradiation Data

July 24, 1984

Oct. 22, 1991

${ }^{249}$ Bk wt., mg

0.0036

0.0014

*Portion of sample lost in dissolution; isotopic data are excellent and reproducible (see Ref. 5, p. 38, for duplicate results). 
Sample data for ${ }^{246} \mathrm{Cm}$, Capsule Position 5

A. Isotopic Composition, at. \%

$\begin{array}{cc} & \text { At start } \\ \text { Date: } & \text { S, 1980 } \\ & \\ 243 & 0.043 \\ 244 & 18.43 \\ 245 & 0.234 \\ 246 & 66.51 \\ 247 & 1.84 \\ 248 & 12.95\end{array}$

\begin{tabular}{c} 
FP-1 \\
Aug. 13, 1984 \\
\hline- \\
- \\
16.03 \\
0.51 \\
67.53 \\
2.52 \\
13.41
\end{tabular}

\begin{tabular}{c} 
FP-2* \\
Nov. 17, 1986 \\
\hline
\end{tabular}

FP-4

B. Concentration, mg ${ }^{246} \mathrm{Cm}$

$\underset{\omega}{\omega}$

At start

6.66

$\overline{14.86}$

July 20, 1990

0.52

68.63

11.78

6.53
2.54

1.78

66.39

13.45

6.32

13.71

After irradiation

6.29

Date of measurement

July 24, 1984

6.10

C. Additional Postirradiation Data:

$$
\begin{aligned}
& { }^{238} \mathrm{Pu} \text {, at. \% } \\
& { }^{239} \mathrm{Pu} \text {, " } \\
& { }^{240} \mathrm{Pu} \text { " " } \\
& { }^{241} \mathrm{Pu} \text {, " } \\
& { }^{244} \mathrm{Pu} \text {, " }
\end{aligned}
$$

Pu wt., mg

Sept. 13,1984
0.024
0.240
97.40
0.86
1.48
$<0.001$

0.27
Nov. 17.1986 June 13,1990

0.016
0.182
97.73
0.54
1.53
$<0.001$

0.42
4.92

Mar. 27, 1990

*Duplicate results reported in Ref. 5, p. 39. 
Sample data for ${ }^{246} \mathrm{Cm}$, Capsule Position 6

A. Isotopic Composition, at. \%

$\begin{array}{cc} & \begin{array}{c}\text { At start } \\ \text { Date: }\end{array} \\ & \text { Aug. 5, 1980 } \\ 243 & 0.043 \\ 244 & 18.43 \\ 245 & 0.234 \\ 246 & 66.51 \\ 247 & 1.84 \\ 248 & 12.95\end{array}$

B. Concentration, $\mathrm{mg}{ }^{246} \mathrm{Cm}$

$\not{b}$

At start

After irradiation

Date of measurement

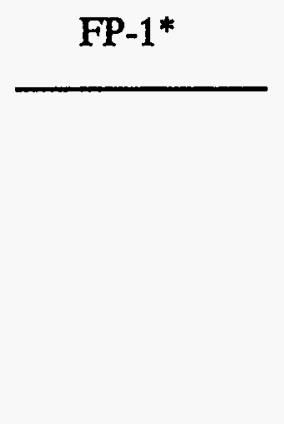

\begin{tabular}{|c|c|}
\hline FP-2 & FP-4 \\
\hline Nov. 18,1986 & July 20,1990 \\
\hline-- & 0.01 \\
\hline 15.00 & 11.80 \\
\hline 0.52 & 1.78 \\
\hline 68.20 & 66.34 \\
\hline 2.52 & 6.34 \\
\hline 13.36 & 13.73 \\
\hline
\end{tabular}

C. Additional Postirradiation Data:

${ }^{238} \mathrm{Pu}$, at. \%
${ }^{239} \mathrm{Pu}$, "
${ }^{240} \mathrm{Pu}, \quad "$
${ }^{241} \mathrm{Pu}, \quad "$
${ }^{242} \mathrm{Pu}, \quad$ "

Pu wt., mg

\subsection{6}

5.24

Jan. 14, 1986

Nov. 14, 1986

0.015
0.159

97.77

0.53

1.53

Not measured
6.80

5.81

Mar. 27, 1990

June 15,1990

0.079

0.096

92.68

5.26

1.88

*Capsule lost during removal from fuel pin. 


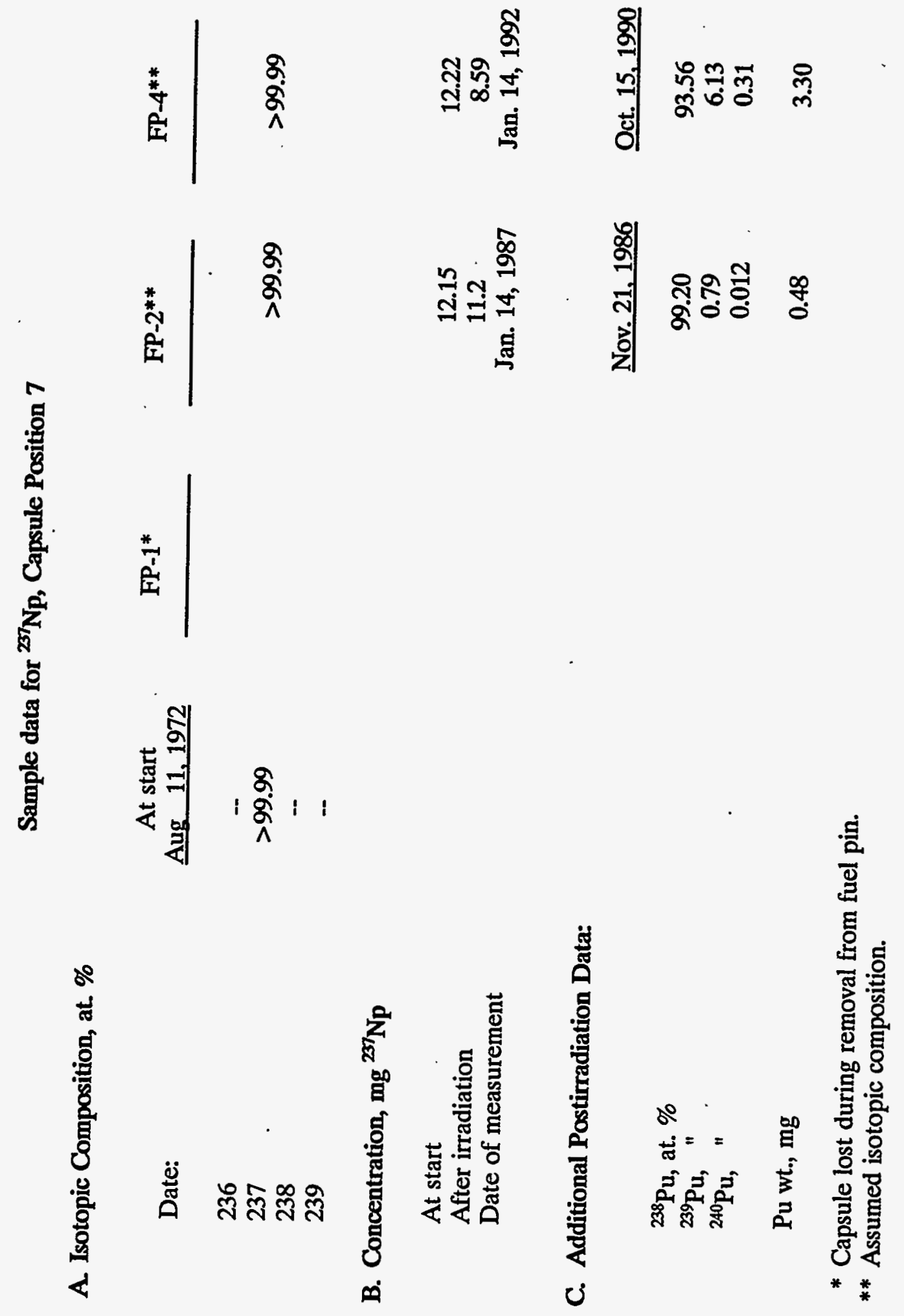


Sample data for ${ }^{2 \mu} \mathrm{Cm}$, Capsule Position 8

A. Isotopic Composition, at. \%

$\begin{array}{lcccc}\text { Date: } & \begin{array}{c}\text { At start* } \\ \text { June 16, 1981 }\end{array} & \begin{array}{c}\text { FP-1** } \\ \text { Aug. 23, 1984 }\end{array} & \begin{array}{c}\text { FP-2 } \\ \text { Nov. 19, 1986 }\end{array} & \text { FP-4*** } \\ 243 & 0.016 & - & - \\ 244 & 92.40 & 89.93 & 89.27 \\ 245 & 1.162 & 2.78 & 2.95 \\ 246 & 6.26 & 7.04 & 7.50 \\ 247 & 0.101 & 0.182 & 0.198 \\ 248 & 0.057 & 0.072 & 0.087^{* * * *}\end{array}$

B. Concentration, $\mathrm{mg}{ }^{2 \mu} \mathrm{Cm}$

bro

At start

8.26

After irradiation

Date of measurement

6.08

Jan. 14, 1987

C. Additional Postirradiation Data:

June 16, 1981

Nov. 14,1986

${ }^{238} \mathrm{Pu}$, at. \%
${ }^{239} \mathrm{Pu}, \quad "$
${ }^{240} \mathrm{Pu}, \quad "$
${ }^{241} \mathrm{Pu}, \quad$ "

0.002

0.048

99.922

0.004

Pu wt., mg

0.73

$\overline{0.017}$

99.33

0.625

0.031

2.07

* Starting ${ }^{244} \mathrm{Cm}$ contained $0.088 \mathrm{mg}{ }^{240} \mathrm{Pu} / \mathrm{mg}$ of ${ }^{244} \mathrm{Cm}$.

** Damaged during removal from fuel pin; no concentration measurement.

*** Lost during removal from fuel pin.

**** Incorrectly reported as 0.987 in Ref. 5, p. 42. 
Sample data for ${ }^{2 \mu} \mathrm{Cm}$, Capsule Position 9

A. Isotopic Composition, at. \%

$$
\begin{aligned}
& \text { Date: } \\
& 243 \\
& 244 \\
& 245 \\
& 246 \\
& 247 \\
& 248
\end{aligned}
$$

\begin{tabular}{c}
$\begin{array}{c}\text { At start } \\
\text { June } 16,1981\end{array}$ \\
\hline \\
\hline 0.016 \\
92.40 \\
1.162 \\
6.26 \\
0.101 \\
0.057
\end{tabular}

\begin{tabular}{c}
$\begin{array}{c}\text { FP-i } \\
\text { ** }\end{array}$ \\
July 25, 1984 \\
\hline- \\
- \\
90.04 \\
2.74 \\
6.96 \\
0.19 \\
0.07
\end{tabular}

FP-2

\begin{tabular}{|c|c|c|}
\hline $\begin{array}{c}8.30 \\
6.60 \\
\text { Sept. } 5,1984\end{array}$ & $\begin{array}{l}8.40 \\
6.08 \\
\text { Jan. 14, } 1987\end{array}$ & $\begin{array}{l}8.25 \\
4.48 \\
\text { March } 26,1990\end{array}$ \\
\hline Sept. 9, 1984 & Nov. 20, 1986 & June 18,1990 \\
\hline$<0.002$ & $<0.002$ & 0.058 \\
\hline 0.018 & 0.017 & 0.021 \\
\hline 99.04 & 99.31 & 93.83 \\
\hline 0.91 & 0.63 & 5.75 \\
\hline 0.031 & 0.038 & 0.34 \\
\hline 1.60 & 2.18 & $\begin{array}{l}2.70 \text { by } \mathrm{RCA}^{* *} \\
2.80 \text { by } \mathrm{IDMS}^{* *}\end{array}$ \\
\hline
\end{tabular}

Nov. 20, 1986

FP-4***

$\underline{\text { July } 13,1990}$

B. Concentration, $\mathrm{mg}{ }^{2 \mu} \mathrm{Cm}$

$\begin{array}{ll} & \text { At start } \\ \text { 范 } & \text { After irradiation } \\ & \text { Date of measurement }\end{array}$

C. Additional Postirradiation Data:

* Starting ${ }^{244} \mathrm{Cm}$ contained $0.088 \mathrm{mg}{ }^{240} \mathrm{Pu} / \mathrm{mg}$ of ${ }^{244} \mathrm{Cm}$.

** Concentration results reported by two methods for quality assurance, radiochemical analysis and isotope dilution mass spectrometry. 
Sample data for ${ }^{213} \mathrm{Cm}$, Capsule Position 10

A. Isotopic Composition, at. \%

Date:

243

244

245

246

247

248

B. Concentration, $\mathrm{mg}^{2 / 3} \mathrm{Cm}$

At start

After irradiation

Date of measurement

C. Additional Postirradiation Data:

None
At start

$\underline{\text { July } 18,1990}$

57.78

40.26

0.96

0.98

$\leq 0.02$

$\leq 0.01$
FP-1

Aug. 9, 1984

56.99

40.09

1.74

1.15

0.03

$<0.01$

0.34

0.33

July 24, 1984
FP-2

Dec. 4, 1986

57.17

39.77

1.85

1.22

$<0.05$

$<0.05$

0.38

0.28

Jan. 14, 1987
FP-4

July 10,1990

43.34

47.06

7.36

2.06

0.16

0.02 
Sample data for ${ }^{238} \mathrm{U}$, Capsule Position 11

A. Isotopic Composition, at. \%

\begin{tabular}{lc} 
Date: & $\begin{array}{c}\text { At start } \\
\text { July 20, 1980 }\end{array}$ \\
\cline { 2 - 2 } 233 & $<0.001$ \\
234 & 0.0015 \\
235 & 0.044 \\
236 & $<0.001$ \\
238 & 99.955
\end{tabular}

B. Concentration, $\mathrm{mg}{ }^{238} \mathrm{U}$

$\begin{array}{cc} & \text { At start } \\ \text { After irradiation } \\ \text { Date of measurement } \\ \text { C. Additional Postirradiation Data: }\end{array}$

\begin{tabular}{c} 
FP-1 \\
June 29,1984 \\
\hline$<0.001$ \\
0.0012 \\
0.047 \\
0.0006 \\
$99.952^{*}$
\end{tabular}

\begin{tabular}{|c|c|}
\hline $\begin{array}{c}\text { FP-2 } \\
\text { Sept. 18, 1986 }\end{array}$ & $\begin{array}{c}\text { FP-4** } \\
\text { July 20, } 1990 \\
\end{array}$ \\
\hline 0.001 & $<0.001$ \\
\hline 0.0016 & 0.002 \\
\hline 0.042 & 0.031 \\
\hline 0.0011 & 0.006 \\
\hline 99.955 & 99.961 \\
\hline
\end{tabular}

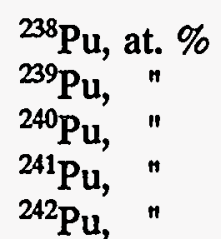

9.86

9.64

June 29, 1984

June 29, 1984

0.012

99.27

0.717

0.003

$<0.001$

Pu wt., mg

0.071
10.33

9.37

Sept. 18, 1986

Sept. 18, 1986 Aug. 13,1990

$<0.01$

99.27

0.724

0.003

$<0.001$

9.81

1.75

0.065
0.076

93.44

6.27

0.206

0.0058

0.105

* Incorrectly reported as 99.940 in Ref. 5, p. 45.

** Portion of sample lost during dissolution. 
FP-4 Sample data for ${ }^{213} \mathrm{Am}$, Capsule Position 12

A. Isotopic Composition, at. \%

Date:

241

242

243

B. Concentration, $\mathrm{mg}^{2 \mathrm{2} 3} \mathrm{Am}$

At start

After irradiation

Date of measurement

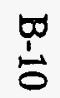

C. Additional Postirradiation Data:
At start

Dec. 19, 1977

0.012

$<0.001$

99.988

FP-1
June 26, 1984
$<0.011$
-
99.988

9.80

9.60

Sept. 5, 1984

June 29, 1984

0.45

20.68

78.87

***

$* *$

${ }^{244} \mathrm{Pu}$, "

Pu wt., mg

${ }^{244} \mathrm{Cm}$, at. \%

${ }^{245} \mathrm{Cm}$, "

${ }^{246} \mathrm{Cm}$, "

Cm wt., mg

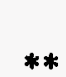

99.16
0.84
0.003

0.34
FP-2

Dec. 2, 1986

0.012

99.987

10.33

9.22

Aug. 14, 1987

6.79

March 27, 1990

Sept. 18, $1986 \quad \underline{\text { June } 11,1990}$

0.12

12.87

87.01

**

**

**

**

99.09

0.91

**

0.31
FP-4

May 21, 1990

$0.030^{*}$

$<0.001$

99.970

* Suspect small ${ }^{241} \mathrm{Pu}$ isobaric contamination; no chemical separation made.

** Signal too weak for valid measurement. 


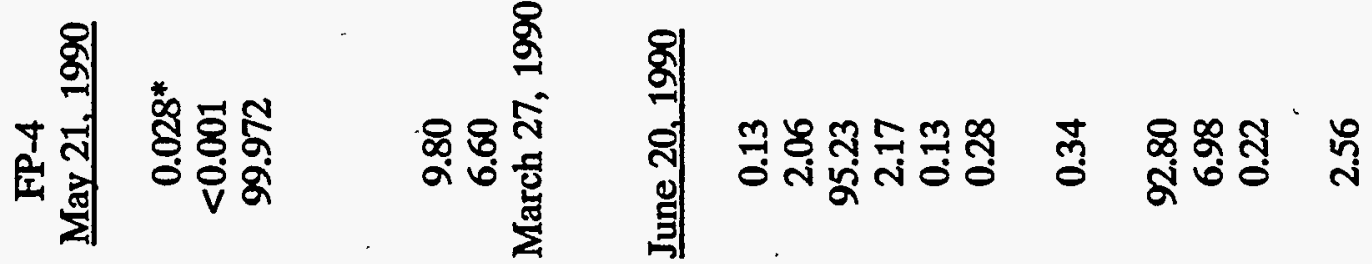

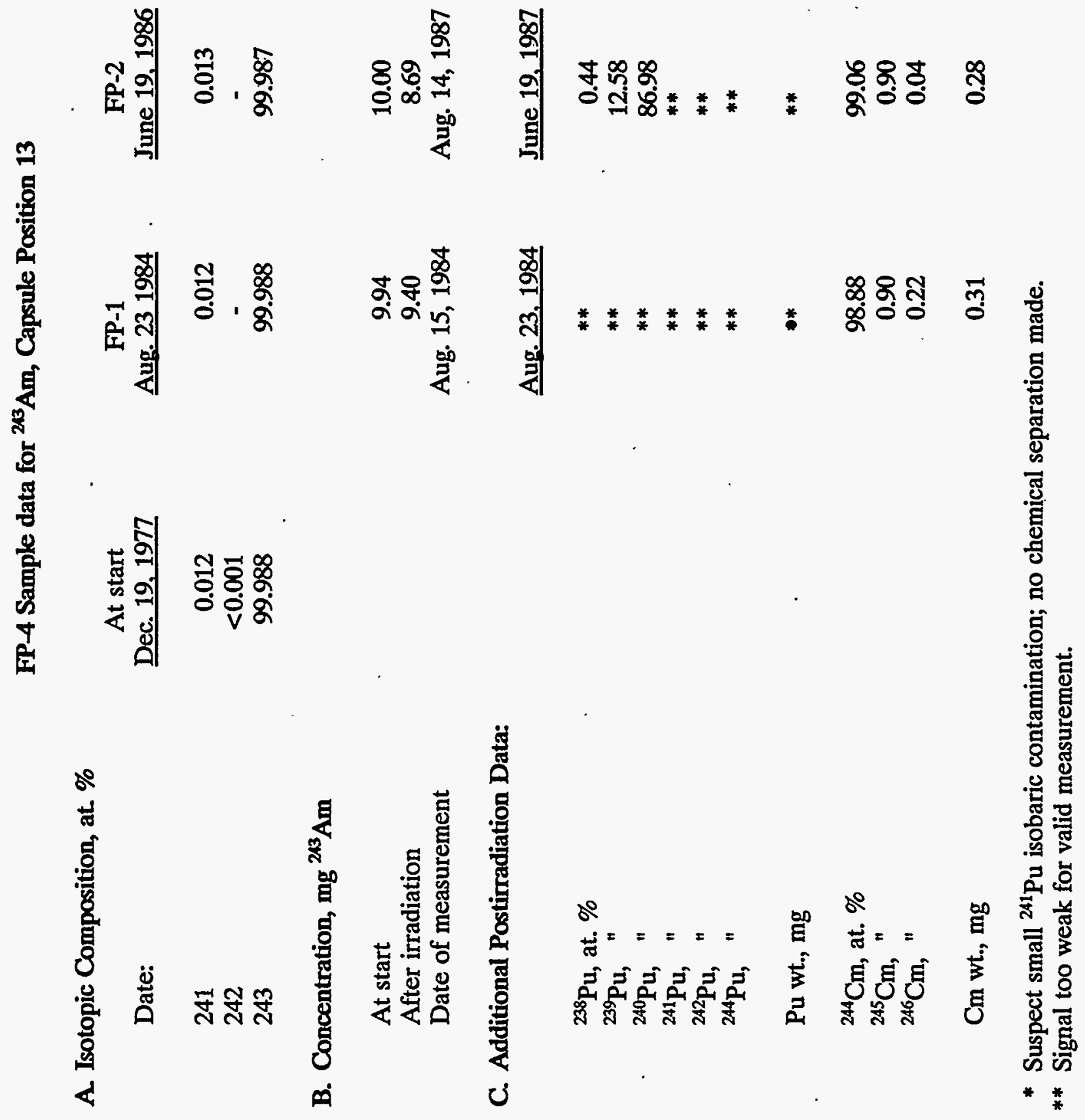


FP-4 Sample data for ${ }^{211} \mathrm{Am}$, Capsule Position 14

A. Isotopic Composition, at. \%

Date:

241

242

243

B. Concentration, mg ${ }^{21 x} \mathrm{Am}$

At start

After irradiation

Date of measurement

C. Additional Postirradiation Data:
At start

Mar. 21, 1981

99.995

$<0.001$

0.004
FP-1 June 29, 1984

99.33

0.66

0.01

10.38

10.10

Sept. 5, 1984

Sept. 5, 1984

99.20

0.50

0.30

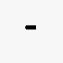

${ }^{238} \mathrm{Pu}$ wt., mg

${ }^{244} \mathrm{Cm}$, at. \%

${ }^{245} \mathrm{Cm}$, "

${ }^{246} \mathrm{Cm}$, "

${ }^{247} \mathrm{Cm}$, "

${ }^{248} \mathrm{Cm}$, "

${ }^{242} \mathrm{Cm}$ wt., mg

0.27

-

$-$

$-$

$-$
FP-2 FP-4

June 18,1987 June 1,1990

99.34

0.65 .

0.01

94.26

5.10

0.64

6.21

June 12, $1987 \quad$ March 26, 1990

0.28

1.92

\begin{tabular}{|c|c|}
\hline Aug. 14, 1987 & June 18,1990 \\
\hline$* *$ & $* *$ \\
\hline 82.04 & 77.75 \\
\hline 0.35 & 4.03 \\
\hline 0.36 & 0.40 \\
\hline 0.082 & 0.02 \\
\hline 17.17 & 17.80 \\
\hline 0.28 & 1.92 \\
\hline
\end{tabular}

95.28

4.16

0.48

0.01

0.07

0.032

* FP-1: no Pu separation made from Am and Cm; unable to measure 241 and 242.

** FP-2, FP-4: Pu separated from Am and Cm; complete isotopic Pu made. 
FP-4 Sample data for ${ }^{211} \mathrm{Am}$, Capsule Position 15

A. Isotopic Composition, at \%

Date:

241

242

243

B. Concentration, $\mathrm{mg}^{2 \mathrm{2n}} \mathrm{Am}$

At start

After irradiation

Date of measurement

C. Additional Postirradiation Data:

菅

\begin{tabular}{c} 
At start \\
Mar. 21, 1981 \\
\hline $\begin{array}{c}99.995 \\
<0.001 \\
0.004\end{array}$
\end{tabular}

Sept. 5, 1984

$\frac{\text { Sept. 5, 1984* }}{95.50}$

${ }^{244} \mathrm{Cm}$, at. \%

${ }^{245} \mathrm{Cm}$, "

${ }^{246} \mathrm{Cm}$,"

${ }^{247} \mathrm{Cm}$, "

${ }^{248} \mathrm{Cm}$, "

${ }^{242} \mathrm{Cm}$ wt., mg
9.55

8.84

3.80

0.70

$-$

0.25

FP-1

99.21

0.78

0.01

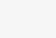

$-$

$-$

$-$

$-$

0.00004
FP-2 June 18, 1987

99.37

0.62

0.01 .

9.39

9.05

June 16, 1987

9.52

6.36

March 26, 1990

Aug. 14, 1987** June 20, 1990**

$82.41 \quad 77.88$

$0.36 \quad 4.07$

$0.12 \quad 0.36$

$0.007 \quad 0.02$

$17.11 \quad 17.66$

$\begin{array}{ll}0.28 & 1.92\end{array}$

- $\quad 95.72$

$-\quad 4.08$

$\begin{array}{ll}- & 1.03\end{array}$

$\begin{array}{ll}- & 0.03\end{array}$

$\begin{array}{ll}- & 0.14\end{array}$

$\begin{array}{ll}0.00006 & 0.032\end{array}$

* FP-1: some contamination; also no Pu separation made from $\mathrm{Am}$ and $\mathrm{Cm}$; unable to measure 241 and 242.

** FP-2, FP-4: Pu separated from Am and Cm; complete isotopic Pu made. 
FP-4 Sample data for ${ }^{212} \mathrm{Pu}$, Capsule Position 16

A. Isotopic Composition, at. \%

Date:
238
239
240
241
242
244
B. Concentration, mg ${ }^{242} \mathbf{P u}$
At start
After irradiation
Date of measurement
$\stackrel{\square}{\dot{\Phi}} \quad$ C. Additional Postirradiation Data:

\begin{tabular}{c} 
At start \\
June 30,1982 \\
\hline 0.124 \\
0.383 \\
1.023 \\
0.093 \\
97.950 \\
0.427
\end{tabular}
Sept. 17, 1984

0.124

3.256

1.990

0.126

94.041

0.462

\begin{tabular}{c} 
FP-2** \\
Oct. 9, 1986 \\
\hline 0.019 \\
0.83 \\
0.98 \\
0.083 \\
97.48 \\
0.514
\end{tabular}

FP-4***

Aug. 14, 1990

0.09

0.25

0.90

0.11

98.30

0.35

$\begin{array}{ll}2.09 & 2.05 \\ 1.67 & 0.78\end{array}$

Oct. 30,1986

Feb. 13, 1991

Oct. 30,1986

July 30,1990

${ }^{241} \mathrm{Am}$, at. \%

8.40

91.60

0.91

99.09

Am wt., mg

0.015

0.06

* Most of FP-1 sample was lost in dissolution: contamination likely, especially in 239, 240, and 241.

** some contamination of FP-2 suspected but of smaller magnitude than in FP-1.

*** Severe sample loss is suspected. 
FP-4 Sample data for ${ }^{2 M} \mathrm{Pu}$, Capsule Position 20

A. Isotopic Composition, at \%

Date:
238
239
240
241
242
244

\begin{tabular}{c}
$\begin{array}{c}\text { At start } \\
\text { July } 30,1981\end{array}$ \\
\hline 0.013 \\
0.040 \\
2.796 \\
0.540 \\
9.036 \\
87.575
\end{tabular}

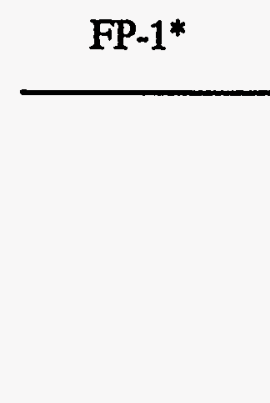

B. Concentration, $\mathrm{mg}{ }^{2 \mathrm{M}} \mathrm{Pu}$

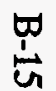

At start

After irradiation

Date of measurement

C. Additional Postirradiation Data:

${ }^{244} \mathrm{Cm}$, at. \%

${ }^{245} \mathrm{Cm}$, "

${ }^{246} \mathrm{Cm}$, "

${ }^{247} \mathrm{Cm}$, "

${ }^{248} \mathrm{Cm}$, "

Cm wt., mg

* Lost during removal from FP-1.
2.14

Oct. 16, 1986

Oct. 16, 1986

0.017

0.038

2.784

0.429

8.995

87.738

\begin{tabular}{c} 
Aug. 15, 1990 \\
\hline 0.094 \\
0.038 \\
2.604 \\
0.426 \\
8.82 \\
88.02
\end{tabular}

88.02

2.11

1.91

Feb. 13, 1991

July 26, 1990

12.42

83.41

4.05

0.13

$<0.01$

0.03 
FP-4 Sample data for ${ }^{210} \mathrm{Pu}$, Capsule Position 21

A. Isotopic Composition, at. \%

$\begin{array}{lc}\text { Date: } & \text { At start } \\ 238 & \text { June } 30,1982 \\ 239 & 0.092 \\ 240 & 0.019 \\ 241 & 99.86 \\ 242 & 0.003 \\ 244 & 0.020 \\ & <0.001\end{array}$

B. Concentration, $\mathrm{mg}{ }^{210} \mathrm{Pu}$

At start

After irradiation

Date of measurement

C. Additional Postirradiation Data:

\begin{tabular}{c} 
FP-1 \\
Sept. 17, 1984 \\
\hline 0.086 \\
0.016 \\
98.85 \\
1.024 \\
0.026 \\
$<0.001$
\end{tabular}

\begin{tabular}{c} 
FP-2 \\
Jan. 9,1987 \\
\hline 0.087 \\
0.015 \\
98.962 \\
0.912 \\
0.025 \\
-0.003
\end{tabular}

FP-4

April 11, 1990

0.168

0.025

91.56

7.74

0.510

$<0.001$

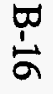

10.78
11.01

Sept. 17, 1984
10.58
9.41
Jan. 9,1987
10.84

10.26

Mar. 22, 1991

June 7, 1990

${ }^{241} \mathrm{Am}$, at. \%

${ }^{242} \mathrm{Am}$, "

${ }^{243} \mathrm{Am}$, "

97.48

1.23

1.29

Am wt., mg 
FP-4 Sample data for ${ }^{20} \mathrm{Pu}$, Capsule Position 22

A. Isotopic Composition, at. \%

\begin{tabular}{c} 
At start \\
June 30,1982 \\
\hline 0.092 \\
0.019 \\
99.86 \\
0.003 \\
0.020 \\
$<0.001$
\end{tabular}

\begin{tabular}{c} 
FP-1 \\
Sept. 17, 1984 \\
\hline 0.088 \\
0.041 \\
98.84 \\
1.005 \\
0.026 \\
$<0.001$
\end{tabular}

\begin{tabular}{c} 
FP-2 \\
Jan. 29, 1987 \\
\hline 0.087 \\
0.015 \\
98.97 \\
0.900 \\
0.026 \\
-0.001
\end{tabular}

FP-4

Date:

238

239

240

241

244

B. Concentration, $\mathrm{mg}{ }^{2 N 0} \mathrm{Pu}$

At start

After irradiation

10.54

11.20

Date of measurement

Sept. 17, 1984

$\stackrel{\leftrightarrow}{\stackrel{\leftrightarrow}{\leftrightarrows}}$

C. Additional Postirradiation Data:

${ }^{241} \mathrm{Am}$, at. \%

${ }^{242} \mathrm{Am}$, "

${ }^{243} \mathrm{Am}$,

Am wt., mg

June 8, 1990

97.48

1.23

1.29

0.113 
FP-4 Sample data for ${ }^{299} \mathrm{Pu}$, Capsule Position 23

A. Isotopic Composition, at. \%

$\begin{array}{lc}\text { Date: } & \text { At start } \\ 238 & \text { Aug. 11, 1972 } \\ 239 & <0.002 \\ 240 & 99.107 \\ 241 & 0.877 \\ 242 & 0.011 \\ 244 & 0.005 \\ & <0.005\end{array}$

B. Concentration, $\mathrm{mg}{ }^{239} \mathrm{Pu}$

At start

After irradiation

7.99

$*$

\begin{tabular}{rrc} 
Sept. 19, 1984 & Feb. 20, 1987 & April 17, 1990 \\
\cline { 1 - 1 } 0.003 & 0.002 & 0.016 \\
97.854 & 97.877 & 84.512 \\
2.115 & 2.094 & 14.640 \\
0.022 & 0.020 & 0.790 \\
0.006 & 0.006 & 0.042 \\
$<0.001$ & $<0.001$ & $<0.005$
\end{tabular}

$\underset{⿱ 艹 \infty}{\infty}$

Date of measurement

C. Additional Postirradiation Data:

\section{None}

* Portion of FP-1 and FP-4 samples was lost in dissolution. 


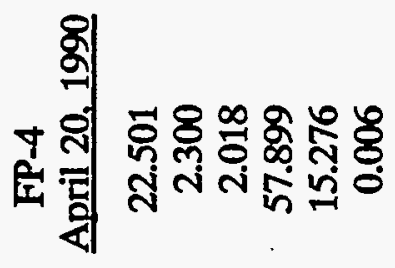

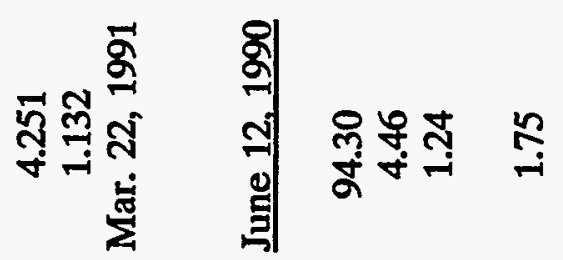
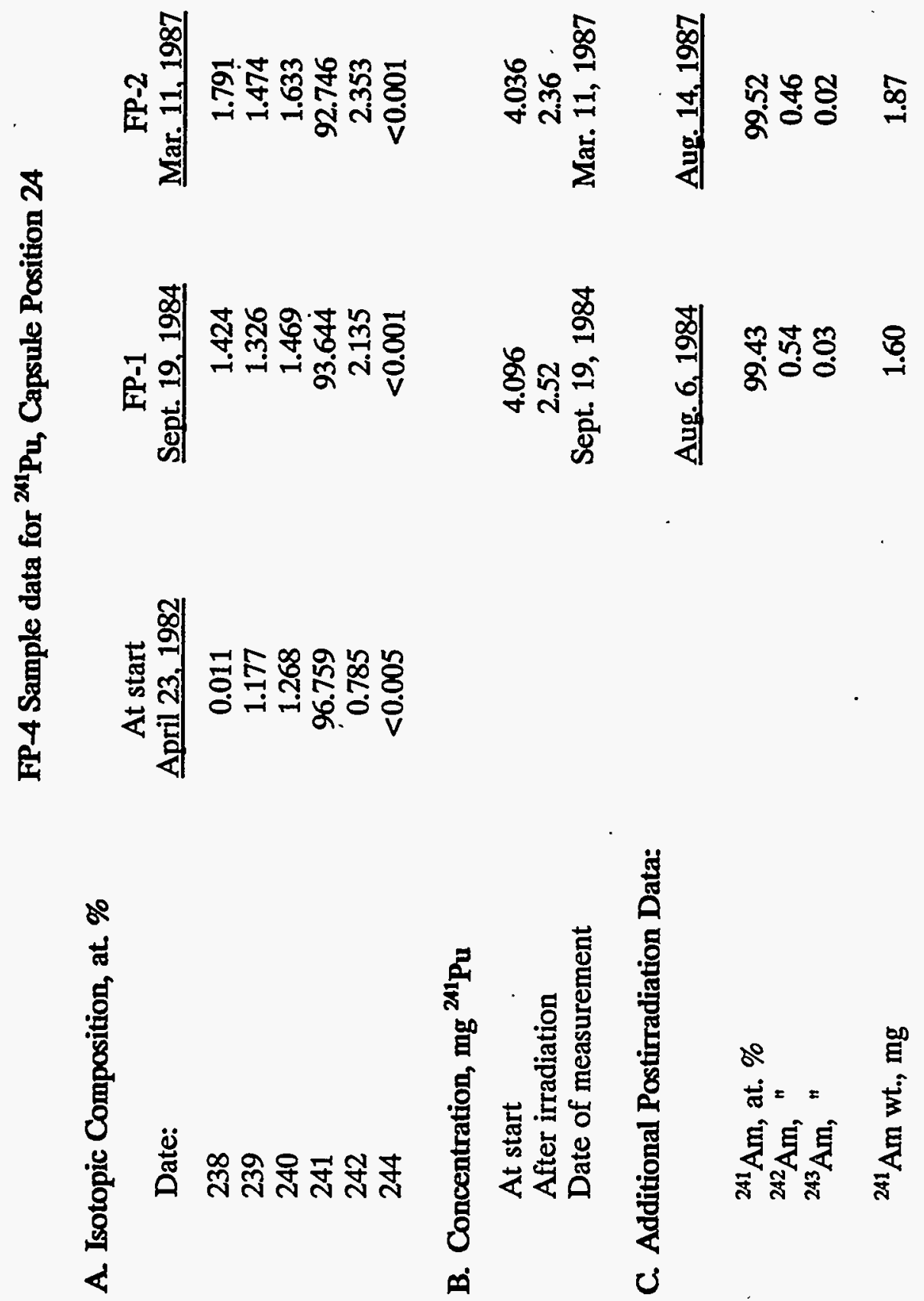


\section{FP-4 Sample data for ${ }^{232} \mathrm{Th}$, Capsule Position 25}

A. Isotopic Composition, at. \%

Date:

232

At start
June 30,1981
100.0

FP-1
Oct. 11, 1984
100.0

FP-2

.

B. Concentration, $\mathrm{mg}^{232} \mathrm{Th}$

At start

After irradiation

Date of measurement

C. Additional Postirradiation Data:

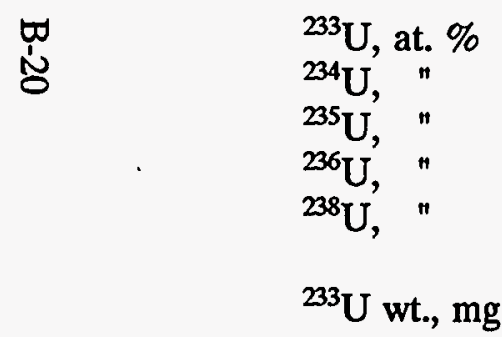

\subsection{7 \\ 17.70}

Oct. 11, 1984

Oct. 11, 1984

99.45

0.55

$-$

$-$

0.15

\section{Mar. 16, 1987}

100.0

Feb. 6, 1991

100.0

18.80

18.11

17.70

Mar. 16, $1987 \quad$ Feb. 6, 1991

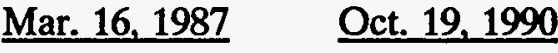

99.60

0.40

95.25

4.54

0.21

$\begin{array}{ll}- & <0.01 \\ - & <0.01\end{array}$

0.16

1.40 
FP-4 Sample data for ${ }^{236} \mathrm{U}$, Capsule Position 26

A. Isotopic Composition, at. \%

Date:
233
234
235
236
238

\begin{tabular}{c}
$\begin{array}{c}\text { At start } \\
\text { July 20, 1981 }\end{array}$ \\
\hline 0.207 \\
0.122 \\
9.352 \\
88.929 \\
1.390
\end{tabular}

\begin{tabular}{c} 
FP-1 \\
June 29, 1984 \\
\hline 0.213 \\
0.123 \\
9.00 \\
89.20 \\
1.46
\end{tabular}

\begin{tabular}{c} 
FP-2 \\
Sept. 18, 1986 \\
\hline 0.152 \\
0.123 \\
9.04 \\
89.25 \\
1.43
\end{tabular}

\begin{tabular}{c} 
FP-4* \\
.ung. 16, 1990 \\
\hline 0.09 \\
0.22 \\
6.21 \\
91.51 \\
1.97
\end{tabular}

B. Concentration, $\mathrm{mg}{ }^{236} \mathrm{U}$

\section{At start \\ After irradiation \\ Date of measurement}

$\underset{\dot{N}}{\stackrel{\sim}{\oplus}}$

C. Additional Postirradiation Data:

${ }^{238} \mathrm{Pu}$, at. \%

${ }^{239} \mathrm{Pu}$, "

${ }^{240} \mathrm{Pu}$, "

${ }^{211} \mathrm{Pu}$, "

${ }^{242} \mathrm{Pu}$, "

Pu wt., mg

${ }^{237} \mathrm{~Np}$ wt., mg

* Severe sample loss is suspected.

\begin{tabular}{|c|c|c|}
\hline $\begin{array}{c}7.91 \\
8.26 \\
\text { June } 29,1984\end{array}$ & $\begin{array}{c}7.92 \\
\quad 7.41 \\
\text { Nov. } 10,1986\end{array}$ & $\begin{array}{c}7.96 \\
3.69 \\
\text { Feb. } 2,1991\end{array}$ \\
\hline June 29,1984 & Sept. 23, 1986 & Aug. 15,1990 \\
\hline 69.50 & 66.10 & 90.65 \\
\hline 30.20 & 33.50 & 8.85 \\
\hline 0.30 & 0.40 & 0.479 \\
\hline - & - & 0.014 \\
\hline - & - & 0.003 \\
\hline 0.003 & 0.002 & 0.09 \\
\hline 0.09 & 0.12 & 0.68 \\
\hline
\end{tabular}




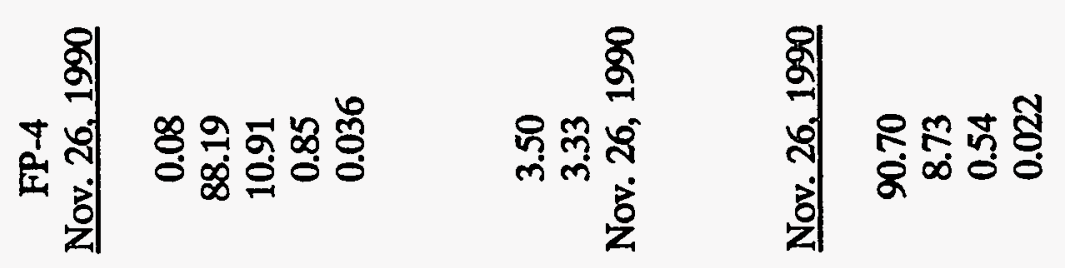
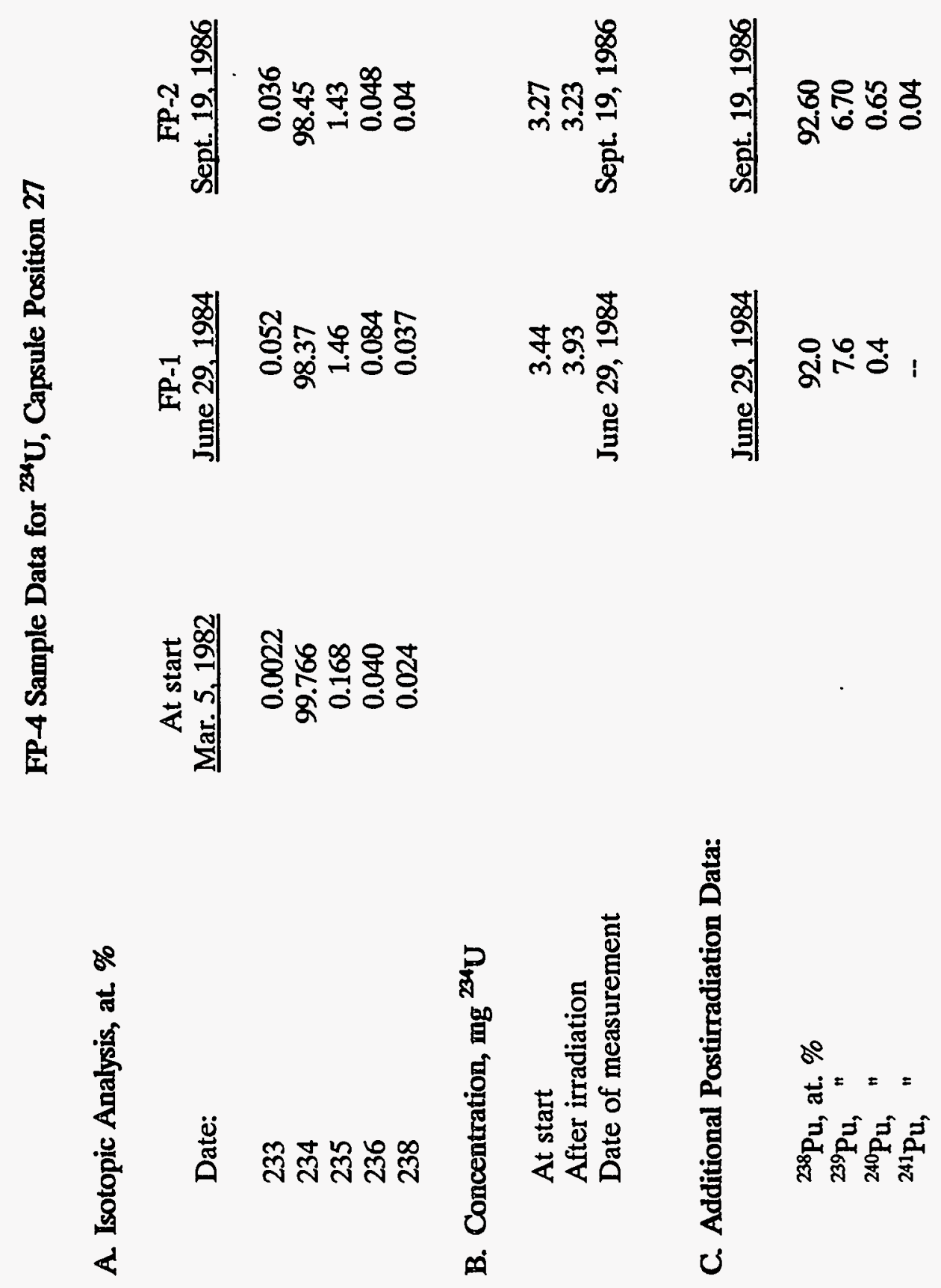


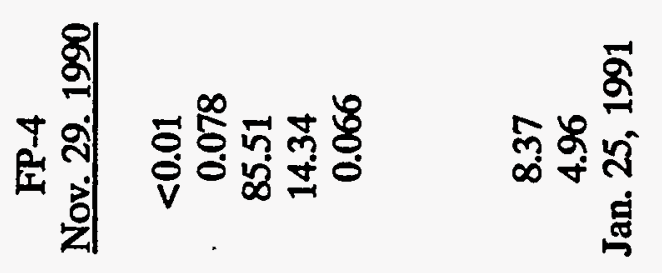
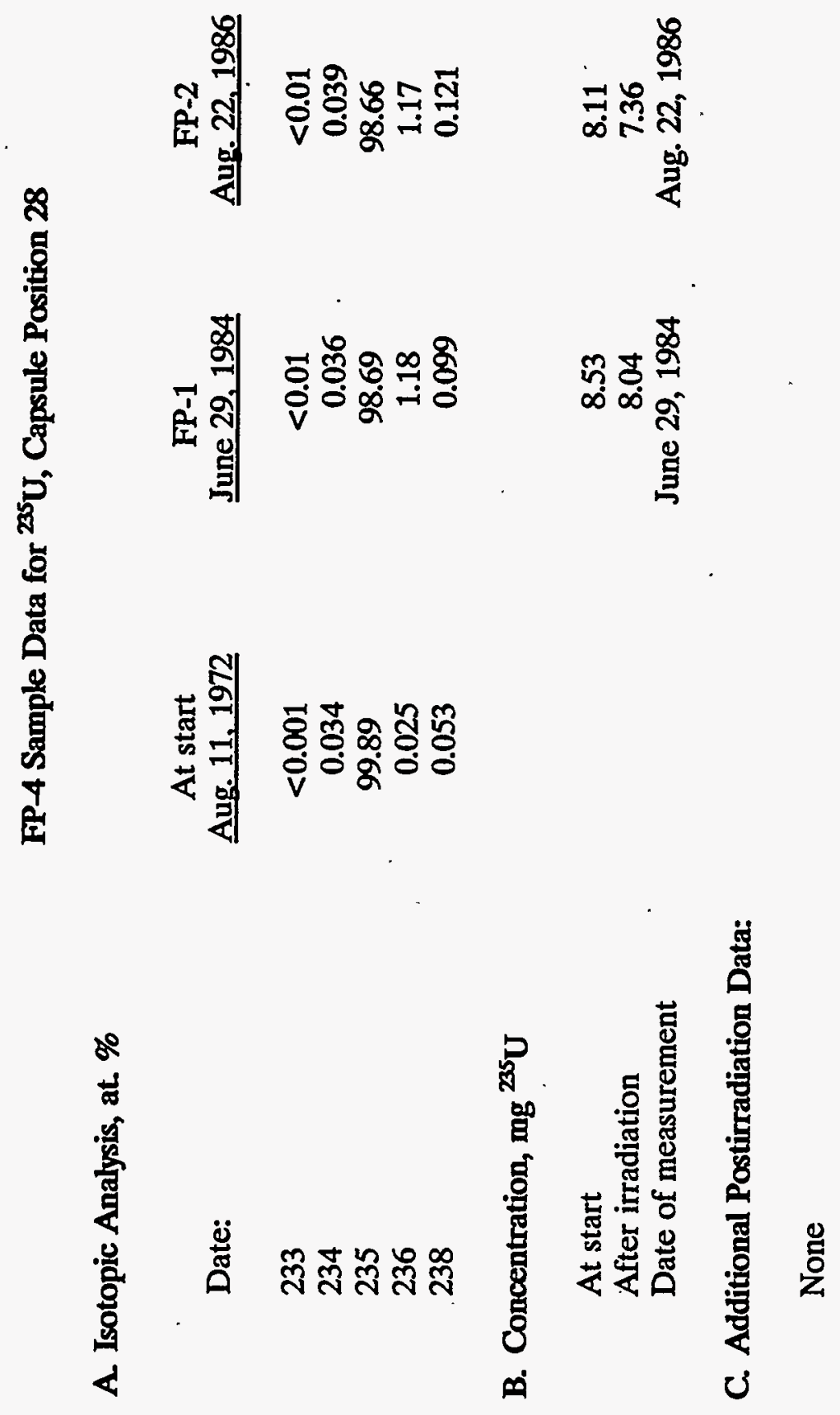
A. Isotopic Composition, at. \%

No measurement required: ${ }^{231} \mathrm{~Pa}, 100 \%$.

B. Concentration, $\mathrm{mg}{ }^{231} \mathbf{P a}$

At start

After irradiation

Date of measurement

\begin{tabular}{|c|c|c|}
\hline FP-1 & FP-2* & FP- $-4 * * *$ \\
\hline $\begin{array}{c}2.89 \\
3.80 \\
\text { Sept. } 5,1984\end{array}$ & & $\begin{array}{c}2.512 \\
0.90 \\
\text { Jan. } 14,1992\end{array}$ \\
\hline Sept. 5, 1984 & & May 31,1990 \\
\hline 0.10 & & 0.41 \\
\hline
\end{tabular}

* Sample lost in dissolving.

** Incorrectly reported as ${ }^{233} \mathrm{U}$ in Ref. 5, p. 60.

*** Some sample loss is suspected. 
Sample Data for ${ }^{238} \mathrm{Pu}$, Capsule Position 30

A. Isotopic Composition, at. \%

\begin{tabular}{lc} 
& At start \\
Date: & June 20, 1972 \\
\cline { 2 - 2 } 238 & 99.39 \\
239 & 0.279 \\
240 & 0.319 \\
241 & $<0.01$ \\
242 & 0.018 \\
244 & $<0.001$
\end{tabular}

\begin{tabular}{ccc} 
FP-1 $^{*}$ & $\begin{array}{c}\text { FP-2** } \\
\text { May 12, 1987 }\end{array}$ & $\begin{array}{c}\text { FP-4*** } \\
\text { April 16, 1990 }\end{array}$ \\
\cline { 3 - 3 } 98.07 & & 86.74 \\
1.54 & 11.89 \\
0.367 & 1.282 \\
0.006 & 0.068 \\
0.019 & 0.026 \\
$<0.001$ & $<0.001$
\end{tabular}

B. Concentration, $\mathrm{mg}{ }^{238} \mathrm{Pu}$

At start
After irradiation
Date of measurement
. C. Additional Postirradition Data:

None

* Not analyzed; damaged while removing from FP-1.

** Portion lost in dissolution.

*** Severe sample loss is suspected.

**** From alpha spectrometry. Isotope dilution mass spectrometry gave $0.80 \mathrm{mg}$. 
Sample Data for ${ }^{200} \mathrm{Th}$, Capsule Position 31

A. Isotopic Composition, at. \%

Date:

At start

230

232

B. Concentration, $\mathrm{mg}{ }^{230} \mathrm{Th}$

At start

After irradiation

Date of measurement

C. Additional Postirradition Data:

芯

None
89.47

10.53

\begin{tabular}{|c|c|}
\hline $\begin{array}{c}\text { FP-2** } \\
\text { Jan. 20, } 1987\end{array}$ & $\begin{array}{c}\text { FP-4 } \\
\text { Feb. 20, } 199\end{array}$ \\
\hline 89.37 & $\begin{array}{l}88.92 \\
1100\end{array}$ \\
\hline
\end{tabular}

2.93

2.66

Jan. 20, 1987
2.88

2.54

Feb. 20, 1991

* Lost in removal from FP-1.

** Small loss of sample from bumping during dissolution. 
FP-4 Sample Data for ${ }^{233}$ U, Capsule Position 32

A. Isotopic Composition, at \%

\begin{tabular}{c} 
At start \\
Mar. 5, 1982 \\
\hline 99.887 \\
0.052 \\
0.0032 \\
0.0018 \\
0.056
\end{tabular}

\begin{tabular}{c} 
FP-1 \\
Nov. 10, 1984 \\
\hline 99.41 \\
0.55 \\
0.005 \\
0.001 \\
0.031
\end{tabular}

\begin{tabular}{|c|c|}
\hline $\begin{array}{c}\text { FP-2* } \\
\text { Sept. 3, } 1986\end{array}$ & $\begin{array}{c}\text { FP-4* } \\
\text { Dec. } 7,1990\end{array}$ \\
\hline 99.36 & 92.01 \\
\hline 0.58 & 7.34 \\
\hline 0.009 & 0.54 \\
\hline 0.002 & 0.031 \\
\hline 0.051 & 0.080 \\
\hline
\end{tabular}

B. Concentration, $\mathbf{m g}^{233} \mathrm{U}$

\begin{tabular}{ll} 
& At start \\
$\forall$ & After irradiation \\
\multirow{N}{*}{} & Date of measurement
\end{tabular}

7.92

7.45

Nov. 10, 1984

C. Additional Postirradition Data:

* Portion lost in dissolution; isotopic data excellent 
Appendix C

ANALYTICAL DATA FOR IRRADIATED DOSIMETERS 


\section{Sample Data for ${ }^{235} \mathrm{U}$, Capsule Position 1}

A. Isotopic Composition, at. \%

$\begin{array}{cc} & \text { At Start } \\ \text { Date: } & \text { Aug. 11, 1972 } \\ & \\ 234 & 0.034 \\ 235 & 99.89 \\ 236 & 0.025 \\ 238 & 0.053\end{array}$

B. Concentration, $\mathrm{mg}{ }^{235} \mathrm{u}$

At start

After irradiation

Date of measurement

1.09

1.09

FP-1

Nov. 27, 1984

FP-2

Oct. 7,1986

$\mathrm{FP}-4$

0.039
98.35
1.55
0.066

0.040

98.38

1.52

0.060

Aug. 8, 1991

0.072

87.42

12.51

م

\section{Additional Postirradition Data:}

None

Note: FP-4 dosimeters $\left({ }^{235} \mathrm{U}\right.$ and $\left.{ }^{238} \mathrm{U}\right)$ in Capsule 1 could not be physically separated before dissolving; therefore, isotopic results assume that all isotopes other than. ${ }^{238} U$ are derived from the ${ }^{235} \mathrm{U}$ dosimeter. 


\section{Sample Data for ${ }^{238} \mathrm{U}$, Capsule Position 1}

A. Isotopic Composition, at. \%

$\begin{array}{lcccc} & \text { At start } & \text { FP-1 } & \text { FP-2 } & \text { FP-4 } \\ \text { Date: } & \text { Aug. 11, 1972 } & \text { Nov. 26, 1984 } & \text { Oct.7, 1986 } & \underline{\text { Aug. 8, 1991 }} \\ 234 & <0.0001 & <0.0005 & <0.0005 & - \\ 235 & 0.0012 & 0.0040 & 0.0012 & - \\ 236 & <0.0001 & <0.0005 & <0.0005 & - \\ 238 & 99.999 & 99.996 & 99.999 & -99.99\end{array}$

B. Concentration, $\mathrm{mg}^{238} \mathrm{u}$

\section{At start \\ After irradiation \\ Date of measurement}

C. Additional Postirradition Data:

$\begin{array}{ccc}1.01 & 1.15 & 1.18 \\ 1.07 & 1.16 & 0.60 \\ \text { Nov. 26, } 1984 & \text { Oct. 7, 1986 } & \text { Oct. 24, 1991 }\end{array}$

Nov. 26, 1984

${ }^{238} \mathrm{Pu}$, at. \%
${ }^{239} \mathrm{Pu}$ " "
${ }^{240} \mathrm{Pu}, "$
${ }^{241} \mathrm{Pu}, "$
${ }^{242} \mathrm{Pu}, "$

$\mathrm{Pu}$, wt., mg

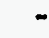

99.20

0.80

0.004

0.001

0.007
Oct. 7, 1986

$-$

99.21

0.79

0.003

0.001

0.009
Aug. 8, 1991

1.072
93.14
5.64
0.140
0.006
0.033

Note: FP-4 dosimeters $\left({ }^{235} \mathrm{U}\right.$ and $\left.{ }^{238} \mathrm{U}\right)$ in Capsule 1 could not be physically separated before dissolving; therefore, results for ${ }^{238} \mathrm{U}$ assume (1) only ${ }^{238} \mathrm{U}$ present in terms of $\mathrm{U}$, and (2) all Pu comes from ${ }^{238} \mathrm{U}$ irradiation. 


\section{Sample Data for ${ }^{299} \mathrm{Pu}$, Capsule Position 2}

A. Isotopic Composition, at. \%

\begin{tabular}{|c|c|c|c|c|}
\hline Date: & $\begin{array}{c}\text { At start } \\
\text { Aug. 11, } 1972 \\
\end{array}$ & $\begin{array}{c}\text { FP-1. } \\
\text { Dec. } 17,1984\end{array}$ & FP-2* & $\begin{array}{c}\text { FP-4 } \\
\text { Aug. 23, 1991 }\end{array}$ \\
\hline 238 & $<0.0002$ & 0.002 & & 21.43 \\
\hline 239 & 99.107 & 97.898 & & 68.26 \\
\hline 240 & 0.877 & 2.072 & & 9.88 \\
\hline 241 & 0.011 & 0.021 & & 0.40 \\
\hline 242 & 0.005 & 0.061 & & 0.026 \\
\hline
\end{tabular}

B. Concentration, mg ${ }^{239} \mathrm{Pu}$

\section{At start}

After irradiation

Date of measurement
1.24

0.58

Jan. 3, 1985
1.20

0.77

Aug. 1, 1991

C. Additional Postirradition Data:

None

Note: FP-4 dosimenters $\left({ }^{237} \mathrm{~Np}\right.$ and $\left.{ }^{239} \mathrm{Pu}\right)$ in capsule 2 could not be physically separated before dissolving; therefore, results show the combined ${ }^{239} \mathrm{Pu}$ left from the original dosimeter and an additional amount produced from the neutron bombardment of the original ${ }^{237} \mathrm{~Np}$.

* Lost in handling. 


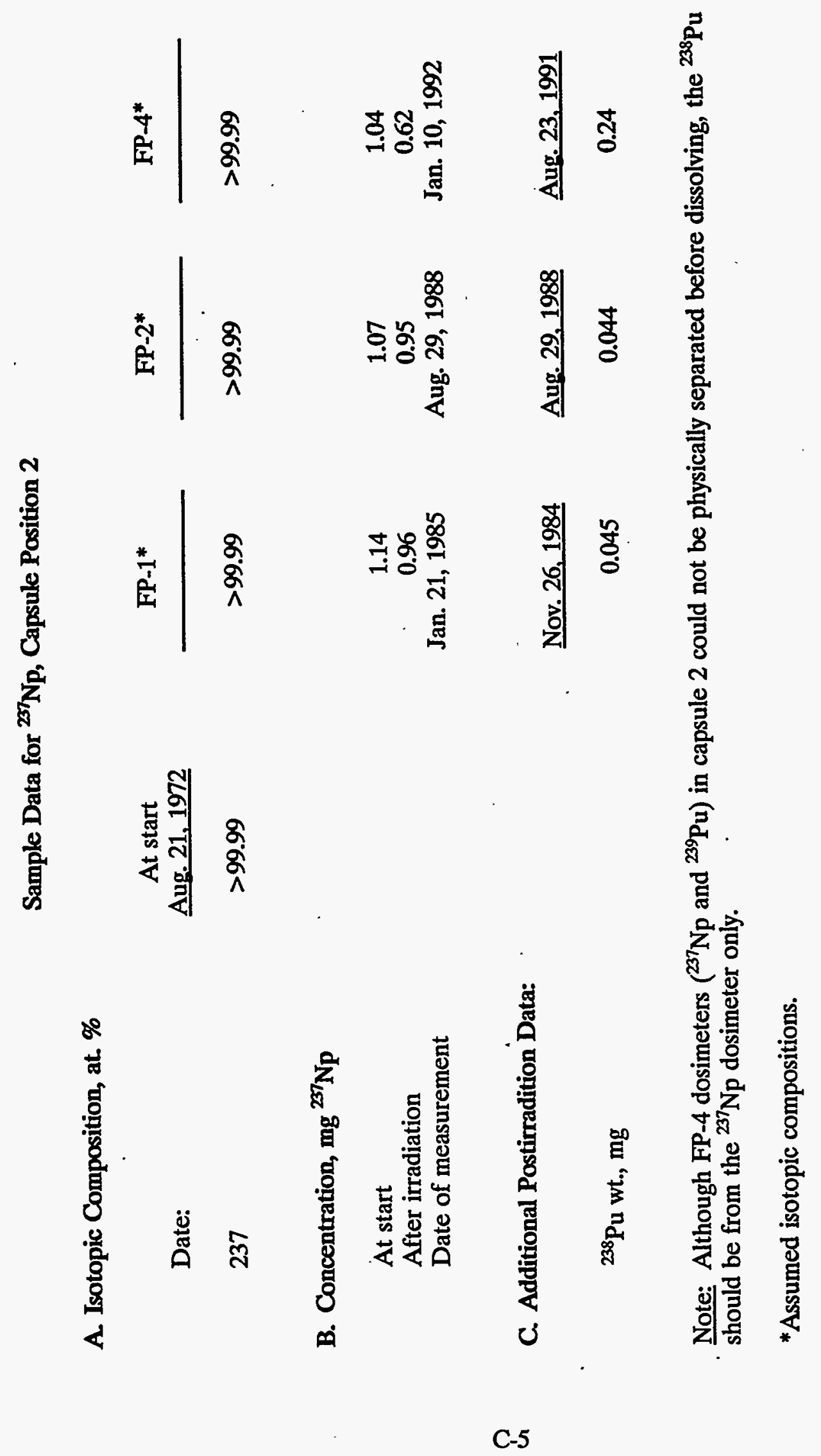




\title{
Sample Data for ${ }^{235} \mathrm{U}$, Capsule Position 17
}

A. Isotopic Composition, at. \%

$\begin{array}{cc} & \text { At start } \\ \text { Date: } & \text { Aug. 11, 1972 } \\ & \\ 234 & 0.034 \\ 235 & 99.89 \\ 236 & 0.025 \\ 238 & 0.053\end{array}$

\begin{tabular}{c} 
FP-1 \\
Nov. 27, 1984 \\
\hline 0.038 \\
98.57 \\
1.325 \\
0.070
\end{tabular}

\begin{tabular}{c} 
FP-2 \\
Aug. 9,1988 \\
\hline 0.040 \\
98.54 \\
1.31 \\
0.11
\end{tabular}

FP-4

ug. 23, 1991

B. Concentration, $\mathrm{mg}^{235} \mathrm{U}$
At start
After irradiation
Date of measurement

1.05

1.03

1.18

1.14

1.11

\author{
Nov. 27, 1984
}

Aug. 9, 1988

Oct. 29, 1991

\section{Additional Postirradition Data:}

\section{None}

Note: FP-4 dosimeters $\left({ }^{235} \mathrm{U}\right.$ and $\left.{ }^{238} \mathrm{U}\right)$ in capsule 17 could not be physically separated before dissolving; therefore, isotopic results assume that all isotopes other than ${ }^{238} U$ are derived from the ${ }^{235} U$ dosimeter. 


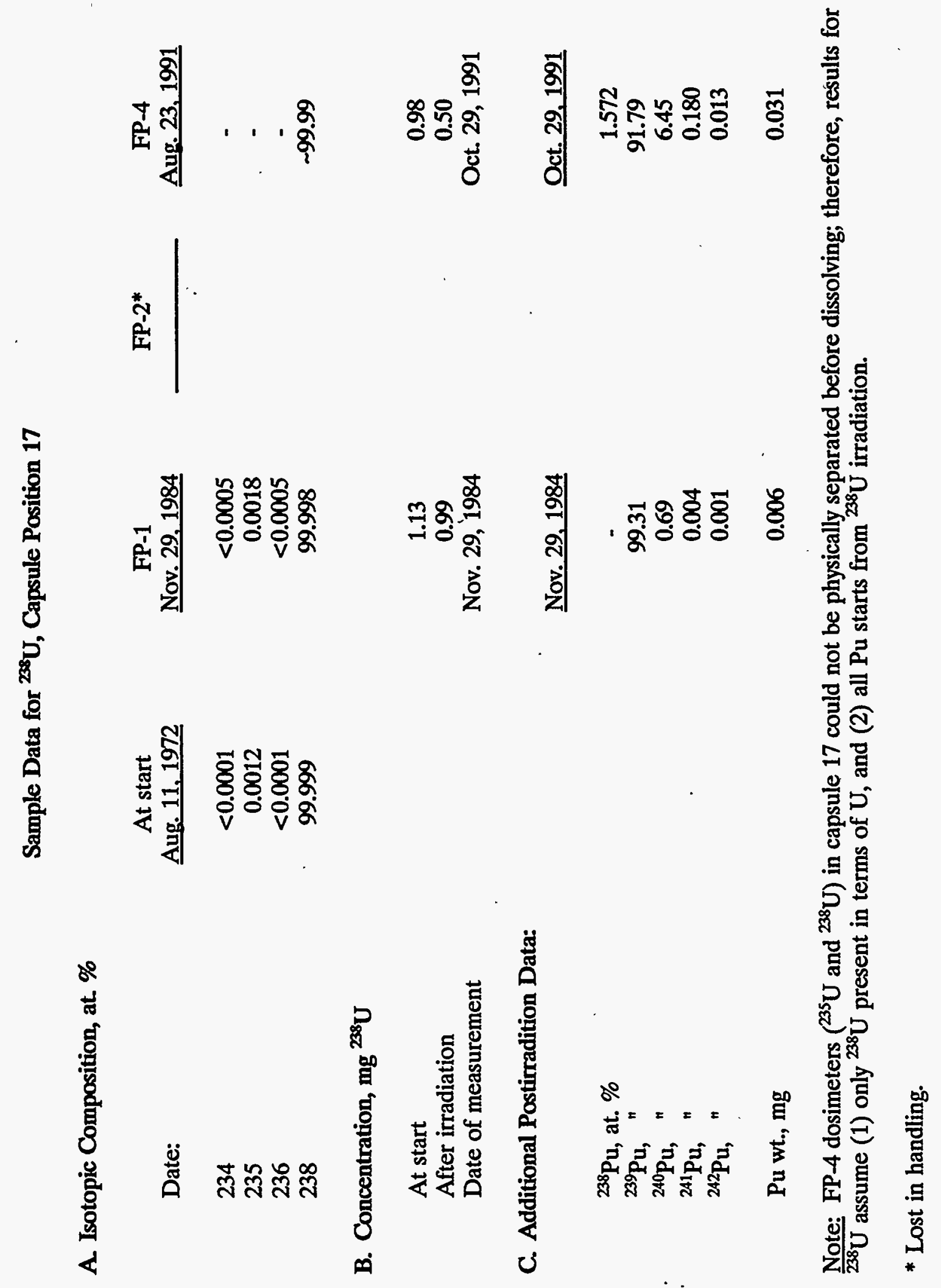

C-7 
Sample Data for ${ }^{239} \mathrm{Pu}$, Capsule Position 18

A. Isotopic Composition, at \%

$\begin{array}{lc} & \text { At start } \\ \text { Date: } & \text { Aug. 11, 1972 } \\ & \\ 238 & <0.002 \\ 239 & 99.107 \\ 240 & 0.877 \\ 241 & 0.011 \\ 242 & 0.005\end{array}$

\begin{tabular}{c} 
FP-1 \\
Dec. 17,1984 \\
\hline- \\
97.81 \\
2.16 \\
0.022 \\
0.006
\end{tabular}

FP-2*

$\mathrm{FP}-4$

Oct. 29, 1991

25.72

63.14

10.57

0.54

0.034

B. Concentration, $\mathrm{mg}{ }^{239} \mathrm{Pu}$
At start
After irradiation
Date of measurement

1.19

0.48

1.12

Dec. 17,1984
0.68

Oct. 29, 1991

\section{Additional Postirradition Data:}

\section{None}

Note: FP-4 dosimeters $\left({ }^{237} \mathrm{~Np}\right.$ and $\left.{ }^{239} \mathrm{Pu}\right)$ in capsule 18 could not be physically separated before dissolving; therefore, results show the combined ${ }^{239} \mathrm{Pu}$ left from the original dosimeter and an additional amount produced from the neutron bombardment of the original ${ }^{237} \mathrm{~Np}$.

* Lost in handling. 


\section{Sample Data for ${ }^{237} \mathrm{~Np}$, Capsule Position 18}

A. Isotopic Composition, at. \%

\begin{tabular}{|c|c|c|c|c|}
\hline Date: & $\begin{array}{c}\text { At start } \\
\text { Aug. 21, } 1972\end{array}$ & FP-1* & FP-2** & FP-4* \\
\hline & $>99.99$ & $>99.99$ & & $>99.99$ \\
\hline
\end{tabular}

B. Concentration, mg ${ }^{237} \mathrm{~Np}$

\section{At start \\ After irradiation \\ Date of measurements}

C. Additional Postirradition Data:
${ }^{238} \mathrm{Pu}$ wt., mg
1.12

1.00

Fèb. 8, 1985

1.12

0.62

Jan. 10, 1992

Dec. 14, 1984

Aug. 23, 1991

0.27

Note: Although FP-4 dosimeters $\left({ }^{237} \mathrm{~Np}\right.$ and $\left.{ }^{239} \mathrm{Pu}\right)$ in capsule 18 could not be physically separated before dissolving, the ${ }^{238} \mathrm{Pu}$ should be from the ${ }^{237} \mathrm{~Np}$ dosimeter only.

* Assumed isotopic composition.

** Lost in handling. 
Sample Data for ${ }^{235}$ U, Capsule Position 33

A. Isotopic Composition, at \%

$\begin{array}{lc} & \text { At start } \\ \text { Date: } & \text { Aug. 11, 1972 } \\ & \\ 234 & 0.034 \\ 235 & 99.89 \\ 236 & 0.025 \\ 238 & 0.053\end{array}$

$\begin{array}{ccc}\text { FP-1 } & \text { FP-2 } & \text { FP-4* } \\ \text { Dec. 11, 1984 } & \text { Aug. 11, 1988 } & \\ 0.037 & 0.040 & \\ 98.73 & 98.73 & \\ 1.15 & 1.13 & \\ 0.085 & 0.100 & \end{array}$

B. Concentration, $\mathrm{mg}{ }^{235} \mathrm{U}$

At start

After irradiation

1.07

1.06

1.16

Date of measurement

Dec. 11,198

1.12

$\stackrel{?}{0}$

C. Additional Postirradition Data:

None

* Lost in handling. 


$$
\text { it }
$$

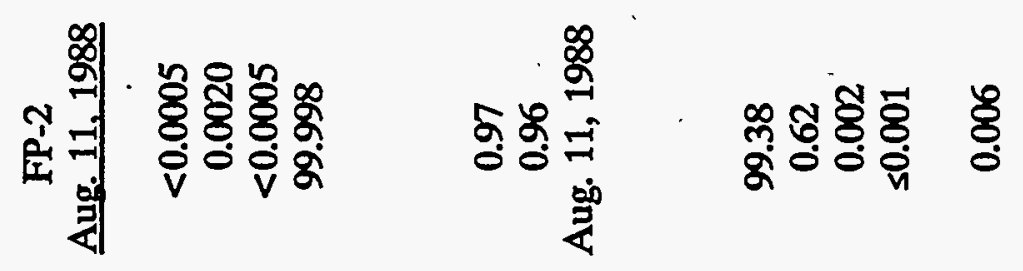
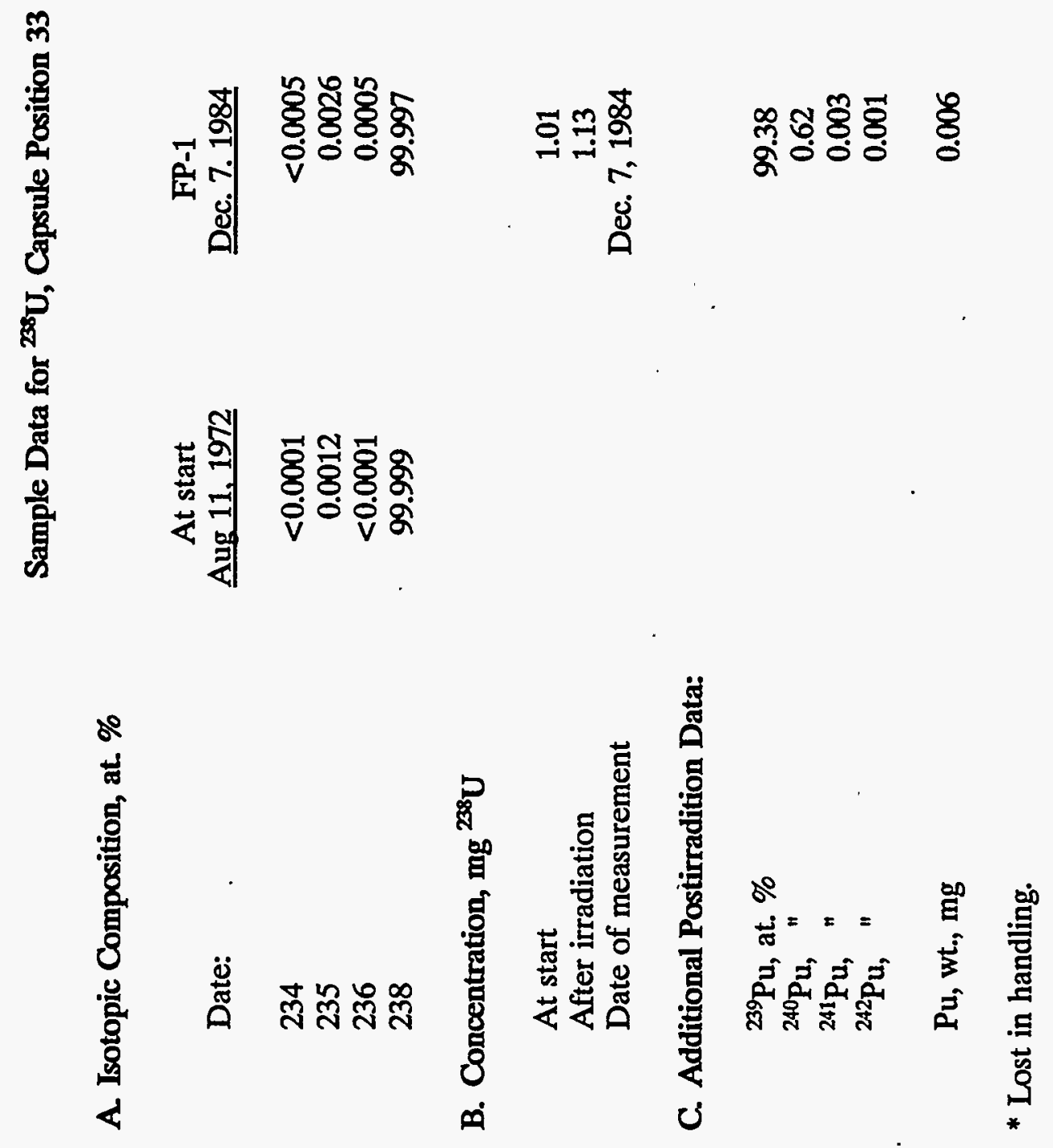

C-11 


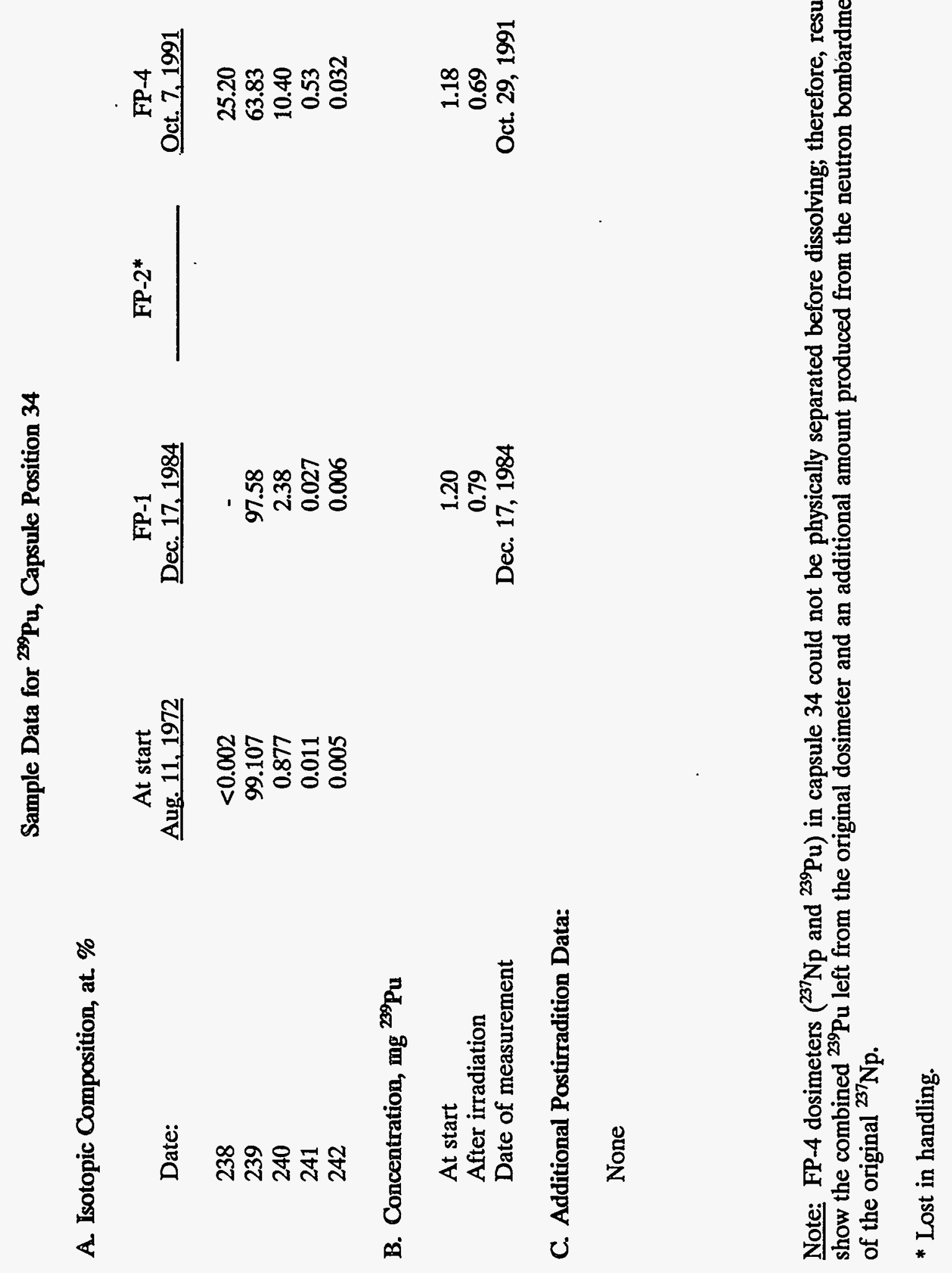




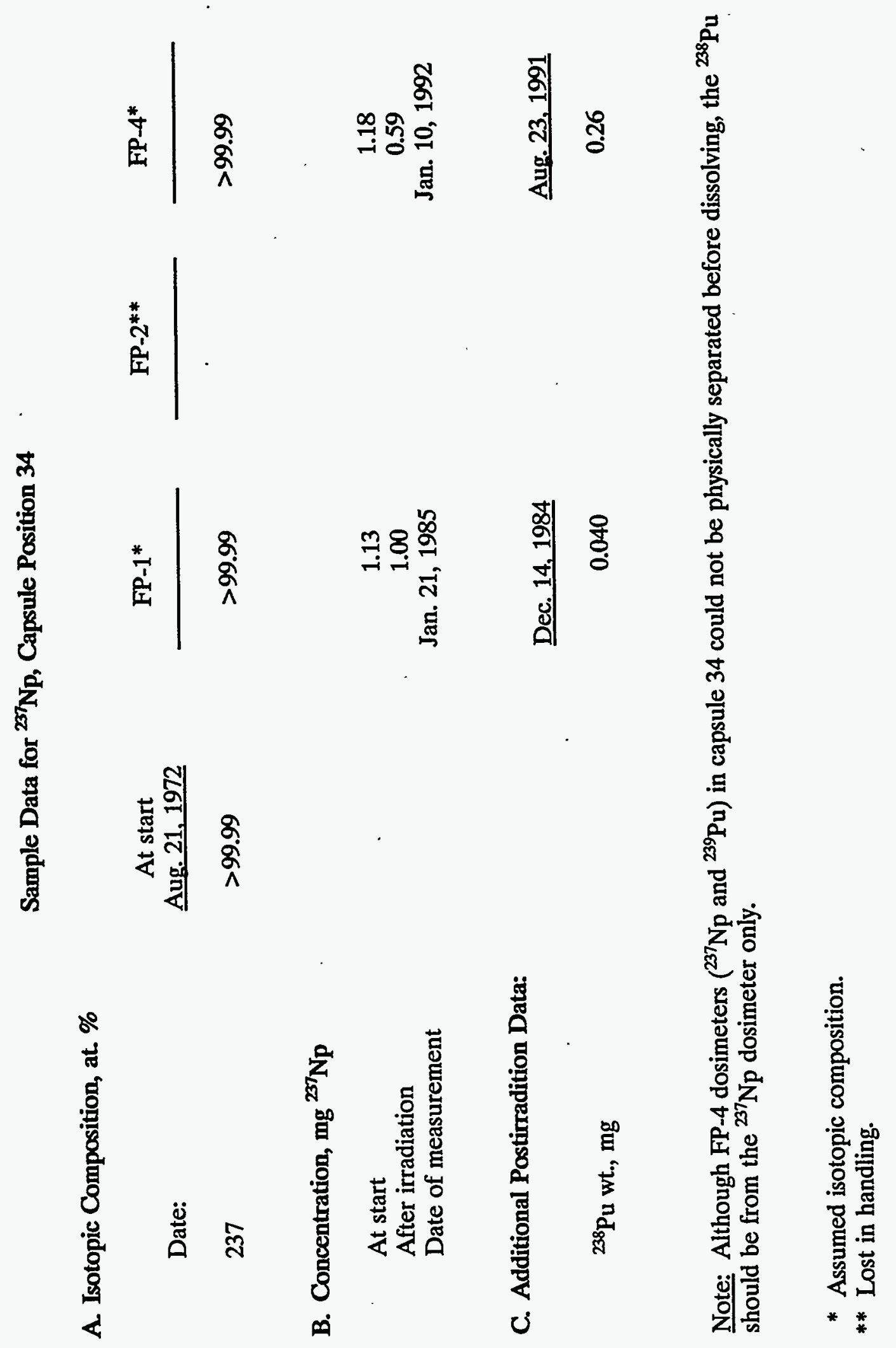

C-13 
ORNL-6837

Dist. Category UCN-534

\section{INTERNAL DISTRIBUTION}

$\begin{aligned} 1 . & \text { J. B. Ball } \\ 2 . & \text { Shirley J. Ball } \\ 3-7 . & \text { F. E. Bertrand } \\ 8 . & \text { J. E. Bigelow } \\ 9 . & \text { J. L. Botts } \\ 10-14 . & \text { B. L. Broadhead } \\ 15-19 . & \text { J. K. Dickens } \\ 20-24 . & \text { R. J. Hydzik } \\ 25-29 . & \text { J. M. Keller } \\ 30-34 . & \text { D. C. Larson } \\ 35 . & \text { A. M. McCoy } \\ 36-40 . & \text { B. D. Murphy }\end{aligned}$

$\begin{aligned} \text { 41-45. } & \text { C. V. Parks } \\ 46 . & \text { M. L. Poutsma } \\ \text { 47-51. } & \text { S. Raman } \\ 52 . & \text { R. F. Sincovec } \\ 53 . & \text { R. L. Walker } \\ 54 . & \text { EPMD Reports Office } \\ 55-56 . & \text { L a b o r a t o r y R e c o r d s } \\ & \text { Department } \\ 57 . & \text { Laboratory Records, ORNL-RC } \\ 58 . & \text { Document Reference Section } \\ 59 . & \text { Central Research Library } \\ 60 . & \text { ORNL Patent Section }\end{aligned}$

\section{EXTERNAL DISTRIBUTION}

61-65. E. R. Adams, Dounreay Nuclear Power Development Establishment, Thurso, Caithness, Scotland, United Kingdom

66-67. Philip B. Hemmig, Advanced Reactor Technology, U.S. Department of Energy, NE-542/GTN, Washington, DC 20585

68-72. T. Mukaiyama, Fast Critical Assembly, Japan Atomic Energy Research Institute, Tokai-mura, Naka-gun, Ibaraki-ken, Japan

73-77. T. Newton, Reactor Physics, Shielding, and Criticality Department, AEA Technology, B20 Winfrith, Dorchester, Dorset, United Kingdom DT2 8DH

78. J. A. Reafsnyder, Deputy Assistant Manager, Energy Research and Development, Department of Energy, Oak Ridge Operations, Post Office Box 2008, Oak Ridge, Tennesse 37831-6269

79-80. E. T. Weber, Manager, Core Technology and Safety, Hanford Engineering Development Laboratory, Post Office Box 1970, Richland, Washington 99352

81. Office of Assistant Manager for Energy Research and Development, DOE Field Office, Oak Ridge, Tennessee 37831

82-141. For distribution as shown in TID-4500, distribution Category US-534 -- LMFBR Physics; Base Technology 